\title{
How Important Is Sovereign Risk in Determining Corporate Default Premia? The Case of South Africa
} Marcel Peter and Martin Grandes 



\title{
IMF Working Paper
}

Monetary and Financial Systems Department

\section{How Important Is Sovereign Risk in Determining Corporate Default Premia? The Case of South Africa}

\author{
Prepared by Marcel Peter and Martin Grandes ${ }^{1}$ \\ Authorized for distribution by Peter Stella
}

November 2005

\begin{abstract}
This Working Paper should not be reported as representing the views of the IMF. The views expressed in this Working Paper are those of the author(s) and do not necessarily represent those of the IMF or IMF policy. Working Papers describe research in progress by the author(s) and are published to elicit comments and to further debate.

The paper analyzes and quantifies the importance of sovereign risk in determining corporate default premia (yield spreads). It also investigates the extent to which the practice by rating agencies and banks of not rating companies higher than their sovereign ("country or sovereign ceiling") is reflected in the yields of South African local-currency-denominated corporate bonds. The main findings are: (i) sovereign risk appears to be the single most important determinant of corporate default premia in South Africa; (ii) the sovereign ceiling (in local-currency terms) does not apply in the spreads of the industrial multinational companies in the sample; and (iii) consistent with rating agency policy, however, the sovereign ceiling appears to apply in the spreads of most financial companies in the sample.

JEL Classification Numbers: F21, F34, G12, G13, G15

Keywords: sovereign risk, corporate risk, sovereign ceiling, default premium, South Africa Author(s) E-Mail Address: marcel.peter@snb.ch; martin.grandes@aup.fr

\footnotetext{
${ }^{1}$ Marcel Peter was an Economist at the Monetary and Financial Systems Department of the IMF when the paper was written. Martin Grandes is Assistant Professor of Economics at the American University of Paris. The authors wish to thank Martin Cihak, Joe Crowley, Xavier Debrun, Harald Finger, Bob Flood, Hans Genberg, Anna Ilyina, Alain Ize, Ulrich Hiemenz, Srichander Ramaswamy, Helmut Reisen, Bjoern Rother, Gary Schinasi, Krishna Srinivasan, Peter Stella, and Amadou Sy for extensive and helpful comments; Candy Perque (World Bank) for answering questions on the rand-denominated IBRD/IFC bonds; and Bernard Claassens and Mark Raffaelli (both at Bond Exchange of South Africa) for their invaluable help on questions about the South African bond market. The authors also acknowledge generous financial support provided by the Swiss Agency for Development and Cooperation to the project that gave rise to this study, carried out at the OECD Development Centre.
} 


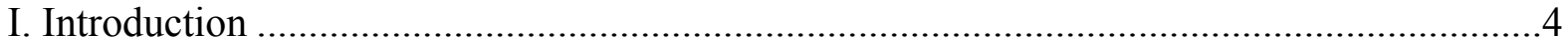

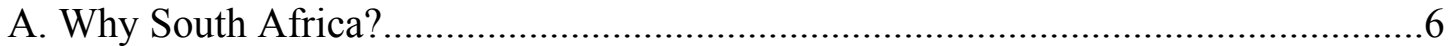

B. Sovereign Risk and the Country or Sovereign Ceiling Rule.................................6

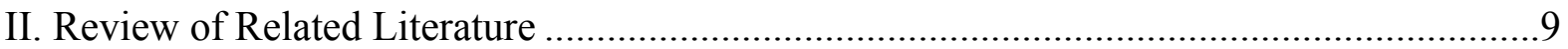

III. Theoretical Framework: Determinants of the Corporate Default Premium .....................11

A. Starting Point: The Merton (1974) Model ................................................................ 12

B. Adding Stochastic Interest Rates: The Shimko, Tejima, and Van Deventer

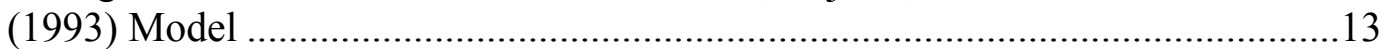

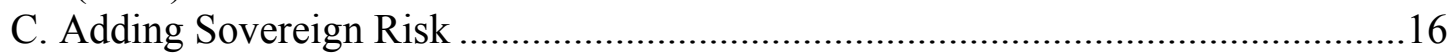

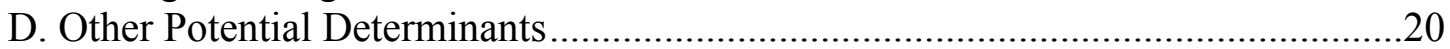

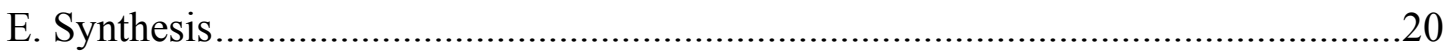

IV. Operationalization of Variables and Data...........................................................21

A. Dependent Variable: How Is the Corporate Default Premium Measured?.............21

B. Explanatory Variables .......................................................................................24

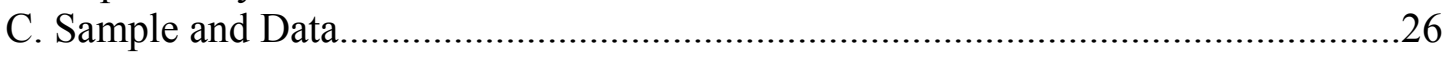

V. Empirical Methodology and Results....................................................................26

A. The Econometric Model: Fixed Effects with Different Slopes for Sovereign

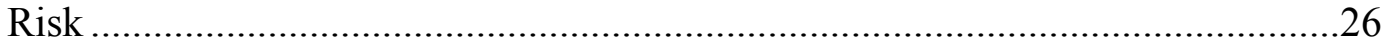

B. Choosing the Appropriate Estimator and First Results .......................................29

C. A Robustness Check: Corporate Spreads in First Differences ..............................31

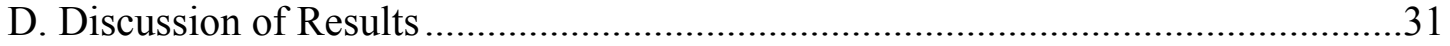

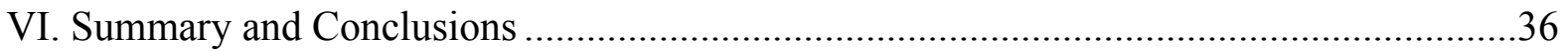

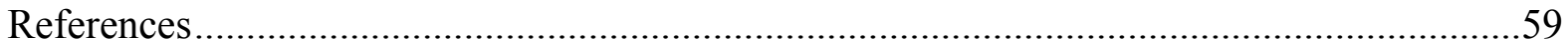

Tables

1. South African Corporate Bonds: Issuers, Main Features, and Corresponding

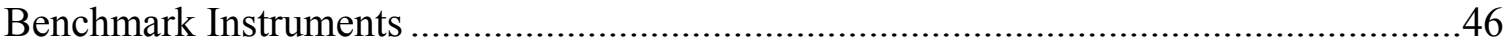

2. History of Credit Ratings by the Republic of South Africa and Firms Analyzed ............47

3. The Determinants of Corporate Default Premia: Expected Impact ...............................48

4. Data Sources and Measurement of Variables ..............................................................49

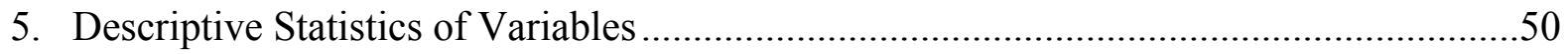

6. The Determinants of Corporate Default Premia: Regressions Results ...........................51

7. The Determinants of Corporate Default Premia: Summary of Empirical Results.............52

8. Variance Decompositions of Corporate Default Premia in Levels and First Differences. 
Figures

1. Firm Bond Yields and Corresponding Sovereign and Risk-Free Yields ........................53

2. South African Corporate Default Premia, July 2000-May 2003 ....................................58

3. South African Sovereign Default Premia, Corresponding to the Corporate Default

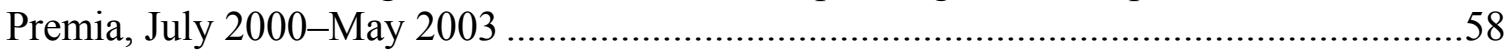

Boxes

1. The Cost of Debt for an Emerging Market Borrower.

Appendices

I. Mathematical Appendix

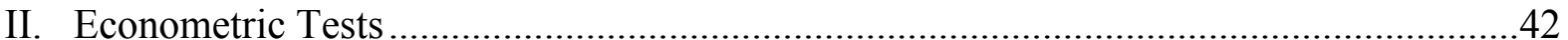

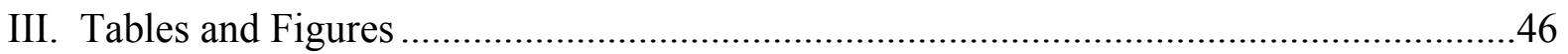




\section{INTRODUCTION}

The cost of capital is an important determinant of economic growth. Emerging market borrowers able to tap international capital markets - be they the government itself or the country's firms - generally pay a considerable risk premium (Box 1) over comparable risk-free assets (such as U.S. Treasury securities). When these debt instruments are

\begin{tabular}{l} 
Box 1. The Cost of Debt for an Emerging Market Borrower \\
Cost of local-currency-denominated debt \\
$\quad=$ \\
Risk-free rate \\
Total risk premium $\left\{\begin{array}{l}\text { 1) Currency (risk) premium } \\
\text { 2) Default (risk) premium } \\
\text { 3) Jurisdiction premium }\end{array}\right\}$ Country (risk) premium \\
\hline
\end{tabular}

denominated in domestic currency, one of the main components of this total risk premium is the currency (risk) premium (sometimes also referred to simply as currency risk ${ }^{2}$ ), which reflects the risk of a depreciation or devaluation of the domestic currency. ${ }^{3}$ A second important component is the default (risk) premium. The default premium reflects the financial health (solvency) of the borrower under consideration and compensates for the risk that the borrower may default, that is, is unable (or unwilling, in the case of a government) to service the debt in full and on time. The third component of the total risk premium is a jurisdiction (or onshore-offshore) premium that is caused by differences between domestic (onshore) financial regulations and international (offshore) legal standards. In the literature, the sum of the default premium and the jurisdiction premium is often called country (risk) premium or simply country risk. Moreover, if the borrower in question is the government itself, the default premium —or the country riskis called the sovereign risk premium or simply sovereign risk.

This paper assesses the importance of sovereign risk in determining local-currencydenominated corporate financing costs, using South Africa as a case study. In particular, it tries to answer the following questions:

- Does sovereign risk help explain corporate default premia? If yes, is a given increase in sovereign risk (measured by the sovereign yield spread), associated

\footnotetext{
${ }^{2}$ This currency risk is not to be confused with the exchange risk that can arise as a result of an investor's risk aversion and/or because of covariance of consumption with exchange rates.

${ }^{3}$ In a companion paper, Grandes, Peter, and Pinaud (2003), we analyze the determinants of the currency premium in South Africa.
} 
with a more or less than proportionate increase in corporate default premia (measured by the corporate yield spread)?

- $\quad$ Can we observe something like a sovereign ceiling in local-currency-denominated corporate yield spreads?

- Do company-specific factors help explain corporate default premia?

The crucial policy issue in this context is the extent to which corporate debt costs can be lowered when public sector solvency improves.

The main findings are, first, sovereign risk appears to be the single most important determinant of corporate default premia in South Africa. For almost all firms analyzed, sovereign risk is statistically and economically the most important determinant of their credit spread. ${ }^{4}$ Second, the sovereign ceiling (in local-currency terms) does not apply in the spreads of the industrial multinational companies in the sample, in the sense that the elasticity of their spreads with respect to sovereign spreads is significantly lower than one (between 0.42 and 0.83 ). Third, consistent with rating agency policy, the sovereign ceiling appears to apply in the spreads of most of the financial companies, with elasticities that are statistically not different from one (between 0.78 and 0.98 ). And fourth, the firm-specific factors derived from the contingent claims approach (leverage, firm-value volatility, remaining time to maturity, and risk-free interest rate volatility) are also statistically significant determinants of corporate spreads, contrary to the findings by Durbin and $\mathrm{Ng}$ (2005); economically, however, their importance is minor.

From a policy perspective, it is interesting to note that although firm-specific factors are significant in explaining the risk premium investors demand to hold corporate debt, a much more important part of this premium can be attributed to macroeconomic risk factors of the country in which a firm operates. Macroeconomic policies oriented toward reducing sovereign default risk, and hence improving a government's credit rating, can result in a significant reduction in the cost of debt capital for corporate borrowers, which in turn can stimulate investment and economic growth.

The study contributes to the literature in at least four dimensions: (i) it is the first to investigate the impact of sovereign risk on local-currency-denominated corporate financing costs; (ii) contrary to existing empirical studies in the field, it also controls for company-specific variables; (iii) it uses an as-yet unexploited dataset from the Bond Exchange of South Africa (BESA); and (iv) in light of the growing importance of local-currency bond issuances in emerging markets, it provides a methodology for further research on the impact of sovereign default risk on corporate spreads.

\footnotetext{
${ }^{4}$ In this paper, the terms default premium, credit spread, yield spread, or simply spread are used as synonyms (see section IV. A).
} 
The rest of this section explains the choice of South Africa as a case study and introduces the concept of the sovereign ceiling. Section II reviews the related literature. Section III introduces the theoretical framework from which the determinants of the corporate default premium are derived. The description and operationalization of the corporate default premium and its determinants follow in section IV. Section V sets forth the empirical methodology to estimate their relative importance and presents and discusses the econometric results. Section VI summarizes the main findings, concludes, and draws some lessons for economic policy and banks' country risk management.

\section{A. Why South Africa?}

We selected South Africa as a case study essentially for three reasons. First, South Africa is one of the few emerging markets to have a corporate bond market in local currency (i.e., the rand). ${ }^{5}$ Admittedly, this market is still very small: during our sample period (July 2000-May 2003), there were only nine South African private sector firms that had a total of 12 bonds outstanding (Table 1 in Appendix III). ${ }^{6}$ However, despite its limited size, the South African corporate bond market has considerable growth potential, according to a recent report by the Rand Merchant Bank (2001). Among the reasons the report mentions are that (i) South African corporates are under-leveraged and will need more debt in the future to optimize their financing structures; (ii) local banks and institutional investors have a great appetite for this asset class because they are significantly underweight in fixed-income instruments compared to their peers in similarly developed capital markets; (iii) as the government has stabilized its fiscal deficits and increasingly resorted to foreign-currency borrowing to bolster its international reserves needed to cope with currency instability, the government's dominant role in the domestic debt market may gradually decrease, which in turn could crowd in demand for corporate bonds. Second, our empirical study uses an as-yet unexploited dataset provided by BESA. Third, the nine corporate issuers mentioned above are important South African companies. Looking at the prospective development of South Africa's corporate bond market, we think the experience of these borrowers could help inform the decisions made by other potential issuers to resort to the local bond market as an alternative source of finance.

\section{B. Sovereign Risk and the Country or Sovereign Ceiling Rule}

Empirically, there has been a high correlation between sovereign defaults and company defaults. That is, it has been very difficult for companies to avoid default once the sovereign of their jurisdiction has defaulted. This historical regularity has been used by

\footnotetext{
${ }^{5}$ In the terminology of Eichengreen and Hausmann (1999), South Africa is one of the few emerging markets not to suffer from the "Original Sin" problem. A country suffers from Original Sin if it cannot borrow abroad in its own currency (the international component) and/or if it cannot borrow in local currency at long maturities and fixed rates even at home (the domestic component).

${ }^{6}$ In addition to the bonds listed in Table 1, Imperial Group, ISCOR, and Standard Bank had a second bond outstanding, namely IPL2, IS57, and SBK4.
} 
all major rating agencies to justify their country or sovereign ceiling policy, which usually means that the debt of a company in a given country cannot be rated higher than the debt of its government. The economic rationale behind the sovereign rating ceiling for foreign-currency debt obligations is direct sovereign_intervention risk, also called transfer risk. The rationale behind the sovereign rating ceiling for domestic-currency debt obligations is what Standard \& Poor's calls "economic or country risk,"7 which we prefer to call indirect sovereign risk.

The term transfer risk (or direct sovereign intervention risk) is usually only used in a foreign-currency context. It refers to the probability that a government with (foreign) debt servicing difficulties imposes foreign exchange payment restrictions (e.g., debt payment moratoria) on otherwise solvent companies and/or individuals in its jurisdiction, forcing them to default on their own foreign-currency obligations. Indirect sovereign risk is the equivalent of transfer risk in domestic-currency obligations. It refers to the probability that a firm defaults on its domestic-currency debt as a result of distress or default of its sovereign. As a matter of fact, economic and business conditions are likely to be hostile for most firms when a government is in a debt crisis. It is indirect sovereign risk that we are primarily concerned about in this paper. Section III.C elaborates on it. Both direct sovereign intervention risk (transfer risk) and indirect sovereign risk are closely related to (pure) sovereign risk. ${ }^{8}$

Until 2001, the "big three" main rating agencies, Moody's Investors Service, Standard \& Poor's, and Fitch Ratings, followed their country or sovereign ceiling policy more or less strictly. They amended it, however, under increasing pressure from capital markets after the (ex post) zero-transfer-risk experience in Russia (1998), Pakistan (1998), Ecuador (1999), and Ukraine (2000). ${ }^{9}$ Moody's - the last among the big three to abandon the strict sovereign ceiling rule-justified the policy shift as follows: "This shift in our analytic approach is a response to recent experience with respect to transfer risk [in Ecuador, Pakistan, Russia, and Ukraine]... Over the past few years, the behavior of governments in default suggested that they may now have good reasons to allow foreign currency payments on some favored classes of obligors or obligations, especially if an entity's default would inflict substantial damage on the country's economy." 10

Under specific and very strict conditions, rating agencies now allow firms to obtain a higher rating than the sovereign of their incorporation (or location). These conditions are stricter for "piercing" the sovereign foreign-currency rating than the sovereign local-currency rating. Bank ratings are almost never allowed to exceed the sovereign ceiling (in both foreign- and domestic-currency terms) because their fate tends to be

\footnotetext{
${ }^{7}$ See Standard \& Poor's (2001, p.1).

${ }^{8}$ Sovereign risk refers in principle to the probability that a government defaults on its debt. The terms sovereign risk, direct/indirect sovereign risk, and transfer risk are, however, often used interchangeably, as for instance in Obstfeld and Rogoff (1996), p. 349.

${ }^{9}$ See Moody's Investors Service (2001b), Standard \& Poor's (2001), Fitch Ratings (2001).

${ }^{10}$ See Moody’s Investors Service (2001a, p.1).
} 
closely tied to that of the government. Table 2 (Appendix III) shows that among the nine firms analyzed, which had a rating by Moody's or Standard \& Poor's, eight were rated at or below the government. The only-temporary-exception was Sasol, a globally operating oil and gas company. It was assigned a BBB foreign-currency credit rating by Standard \& Poor's on February 19, 2003 - about three months before the government's foreign-currency rating was itself upgraded to BBB (May 7) from BBB minus. All other rated firms in our sample were rated at or below the sovereign ceiling for both foreignand local-currency ratings. Moreover, as the table indicates, four of the five banks or financial firms (ABSA Bank, Investec Bank, Nedcor, and Standard Bank) have always been rated at the sovereign ceiling.

One of the two objectives of this study is to analyze the extent to which a sovereign ceiling can be observed in rand-denominated corporate yield spreads. ${ }^{11}$ This entails, in a first step, verifying whether the bond yields (spreads) of the firms analyzed are always higher than comparable yields (spreads) of government bonds. As panels 1 through 12 of Figure 1 (Appendix III) show, all South African corporate bonds analyzed indeed bear higher yields than sovereign bonds of similar maturity and coupon.

However, corporate spreads exceeding comparable government spreads are only a necessary but not a sufficient condition for the existence of a sovereign ceiling in corporate spread data: the spread of a given firm may be higher than a comparable government spread because the firm, on a stand-alone basis (i.e., independently of the creditworthiness of the government in whose jurisdiction it is located), has a higher default probability than that government. Recall that the spread is essentially a compensation that an investor requires for the expected loss rate he faces on an investment, the expected loss rate $(E L)$ being the product of the probability of default $(P D)$ times the loss-given-default rate $(L G D)$, that is, $E L=P D \cdot L G D$. Thus, whenever we observe rand-denominated corporate spreads that exceed comparable government spreads, we will have to find out whether these observations are due to a high stand-alone default probability of the firm or to high indirect sovereign risk. Section III.C provides a framework to disentangle the different risks.

Confronted with this identification problem, we will resort to a result obtained by Durbin and $\mathrm{Ng}(2005)$. They show in a simple theoretical model that the rating agencies' main justification for the sovereign ceiling rule-namely, that whenever a government defaults, firms in the country will default as well (i.e., transfer risk is 100 percent) implies that a 1 percent increase in the government spread should be associated with an increase in the firm spread of at least 1 percent. We will use this finding to more systematically study the overall impact of sovereign risk on corporate spreads in South Africa. In particular, we will apply Durbin and Ng's finding and estimate the elasticity of corporate bond yield spreads with respect to sovereign yield spreads in order to test whether the sovereign ceiling applies for the firms analyzed. Apart from Durbin and $\mathrm{Ng}$

\footnotetext{
${ }^{11}$ In terms of spreads, the sovereign ceiling (in ratings) translates into a sovereign floor. We stick to the "ceiling" terminology to be consistent with the literature in this field.
} 
(2005), there are no empirical investigations available on that subject to our knowledge. Unlike Durbin and Ng (2005), we will also control for firm-specific variables derived from the literature on corporate debt pricing.

\section{REVIEW OF RELATED LITERATURE}

The present study is closest in spirit to Durbin and Ng (2005). Both are interested in (i) assessing whether a sovereign ceiling can be observed in corporate yield spreads, and (ii) quantifying the impact of sovereign risk on corporate financing costs. The main differences are threefold. First, while Durbin and Ng (2005) analyze the relationship between corporate and sovereign yield spreads on foreign-currency bonds in emerging markets, we study this relationship between corporate and sovereign yield spreads on domestic-currency bonds. Second, Durbin and Ng (2005) work with a broad cross-section of over 100 firm bonds from various emerging markets, while we work with all domesticcurrency-denominated and publicly traded firm bonds available in one particular emerging economy, South Africa. ${ }^{12}$ Third, we also control for firm-specific determinants (e.g., leverage and asset volatility) in our assessment of the impact of sovereign risk on corporate default premia, while this is not the case in Durbin and $\mathrm{Ng}$ (2005).

Durbin and $\mathrm{Ng}$ (2005) argue that the existence of a sovereign ceiling in yield data would imply two things. First, if firms are always riskier than their governments (the rating agencies' first justification for the sovereign ceiling), then there should be no instance where a given corporate bond has a lower yield spread than an equivalent sovereign bond issued by the firm's home government. Second, Durbin and $\mathrm{Ng}$ (2005) show in a simple theoretical model that the rating agencies' main justification for the sovereign ceiling rule - namely, that whenever a government defaults, firms in the country will default as well (i.e., that transfer risk is 100 percent) - implies that a 1 percent increase in the government spread should be associated with an increase in the firm spread of at least 1 percent. In other words, in a regression of corporate spread changes on corresponding sovereign spread changes, the beta-coefficient should be greater than or equal to one.

With respect to the first argument, they find that the corporate and sovereign bond yield spreads in their sample are not fully consistent with the application of the sovereign ceiling rule: several firms have foreign-currency bonds that trade at significantly lower spreads than comparable bonds of their government. With respect to the second argument, they find that when the "riskiness" of the country of origin is not controlled for, the beta-coefficient is indeed slightly larger than one. However, when the riskiness of the country of origin is taken into account, they find that the beta-coefficient is significantly smaller than one for corporate bonds issued in "low-risk" and "intermediate-risk" countries but significantly higher than one in "high-risk" countries. ${ }^{13}$

\footnotetext{
${ }^{12}$ We actually take all publicly traded bonds of South African firms whose shares are quoted on the Johannesburg Stock Exchange (JSE).

${ }^{13}$ The 13 countries for which U.S.-dollar-denominated corporate bond yields were available have been ranked by average government spreads; the "low-risk" group is composed of the five countries with the
} 
They conclude that in relatively low-risk countries, market participants judge transfer risk to be less than 100 percent, that is, "they do not believe the statement that firms will always default when the government defaults."14 As a consequence, the second justification for the sovereign ceiling rule would be invalidated in these cases.

Apart from Durbin and $\mathrm{Ng}$ (2005), there seems to be very little research on the determinants of corporate default risk in emerging markets. We know of no other theoretical or empirical study that investigates the relationship between sovereign risk and corporate debt pricing in an emerging market environment. This lack seems to be due to the fact that most of these corporate bond markets are not yet well developed.

There are, however, two related literature strands. First, there is a wealth of theoretical and empirical studies on the determinants of corporate default risk premia in industrial countries or, more specifically, in the United States. ${ }^{15}$ The distinguishing feature of industrial countries - and the United States in particular - is that government bonds are risk-free (i.e., sovereign risk is zero). This is in sharp contrast to emerging markets where - almost by definition - government bonds are not risk-free. In an emerging market, the corporate yield spread above an equivalent government bond yield does not reflect corporate default risk, even after controlling for all other factors. It merely reflects corporate default risk in excess of sovereign default risk. Hence, it appears that in emerging economies there is a crucial additional determinant of corporate default risk: the default risk of the government, i.e., sovereign risk. Sovereign risk is precisely what the rating agencies' sovereign ceiling rule is all about. Section III.C elaborates on this idea.

The second strand of related literature concerns the empirical studies that assess the determinants of government yield spreads (i.e., sovereign default risk premia) in emerging markets. ${ }^{16}$ Most of these studies identify the classical sovereign default risk determinants, such as total indebtedness (debt/GDP ratio), debt service burden (debt/exports ratio or debt service-to-GDP ratio), level of hard currency reserves (reserves/import or reserves/GDP ratio), economic growth, and others. However, they completely ignore the relationship between sovereign and corporate default risk.

lowest spreads, the "intermediate-risk" group of the next five countries, and the "high-risk" group of the three with the highest spreads. See Durbin and $\mathrm{Ng}$ (2001, p. 30).

${ }^{14}$ Durbin and Ng (2001, p. 19).

${ }^{15}$ Examples are Fisher (1959), Black and Scholes (1973), Merton (1974), Cook and Hendershott (1978), Ho and Singer (1984), Shimko, Tejima, and Van Deventer (1993), Athanassakos and Carayannopoulos (2001), Elton and others (2001).

${ }^{16}$ Examples are Edwards (1984), Edwards (1986), Boehmer and Megginson (1990), Eichengreen and Mody (1998), Westphalen (2001). 


\section{Theoretical Framework: Determinants of THE CoRPorate Default PREMIUM}

The theoretical literature on the pricing of defaultable fixed-income assets — also called credit risk pricing literature — can be classified into three broad approaches: ${ }^{17}$ (i) the classical or actuarial approach; (ii) the structural approach, or firm-value or option theoretic approach, sometimes also referred to as contingent claims approach; and (iii) the reduced-form or statistical or intensity-based approach. The basic principle of the classical approach is to assign (and regularly update) credit ratings as measures of the probability of default of a given counterparty, to produce rating migration matrices, and to estimate (often independently) the value of the contract at possible future default dates. Typical users of this approach include the rating agencies (at least in the traditional part of their operations) and the credit risk departments of banks. ${ }^{18}$ The structural approach is based on Black and Scholes (1973) and Merton (1974). ${ }^{19}$ It relies on the balance sheet of the borrower and the bankruptcy code to endogenously derive the probability of default and the credit spread, based on no-arbitrage arguments and making some additional assumptions on the recovery rate and the process of the risk-free interest rates. The reduced-form approach models the probability of default as an exogenous variable calibrated to some data. The calibration of this default probability is made with respect to the data of the rating agencies or to financial market series acting as state variables. $^{20}$

We adopt the simplest version of the structural approach as the theoretical framework for our investigation, as the classical approach is both too subjective and too backwardlooking and the reduced-form approach is atheoretical with respect to the determinants of default risk. In four steps, the determinants of corporate default risk are derived. In the first step, we recapitulate briefly the Merton (1974) model of risky debt valuation. In the second step, Merton's assumption of a constant risk-free interest rate is relaxed and stochastic (risk-free) interest rates à la Shimko, Tejima, and Van Deventer (1993) are introduced. In the third step, we relax the assumption that government bonds are risk-free, that is, we allow for sovereign (credit) risk; we introduce (in an admittedly ad hoc fashion) the sovereign default premium as an emerging-market specific, additional determinant of corporate default risk. In the fourth step, we briefly consider some potential further determinants that result once the frictionless market assumption is

\footnotetext{
${ }^{17}$ This paragraph draws on Cossin and Pirotte (2001).

${ }^{18}$ For a survey of these methods, see for instance Caouette, Altman, and Narayanan (1998).

${ }^{19}$ Other important contributions to this approach include Shimko, Tejima, and Van Deventer (1993), Longstaff and Schwartz (1995), Saá-Requejo and Santa Clara (1997), Briys and De Varenne (1997), and Hsu, Saá-Requejo, and Santa Clara (2002).

${ }^{20}$ Readers interested in reduced-form models are referred to the works of Pye (1974), Litterman and Iben (1991), Fons (1994), Das and Tufano (1996), Jarrow and Turnbull (1995), Jarrow, Lando, and Turnbull (1997), Lando (1998), Madan and Unal (1998), Duffie and Singleton (1999), Collin-Dufresne and Solnik (2001) and Duffie and Lando (2001), most of which are surveyed and nicely put into a broader context by Cossin and Pirotte (2001), and Bielecki and Rutkowski (2002).
} 
relaxed or specific bond indenture provisions are taken into account. A final subsection synthesizes and summarizes the determinants identified.

\section{A. Starting Point: The Merton (1974) Model}

Merton (1974) uses the option pricing theory developed by Black and Scholes (1973) to the pricing of corporate debt (the so-called contingent claims analysis). Merton's model hinges on a number of critical assumptions. They are: (i) competitive and frictionless markets; (ii) constant risk-free interest rates (i.e., flat-term structure of interest rates); (iii) the firm holds a single type of liability: a non-callable zero-coupon bond; (iv) the value of the firm follows a geometric Brownian motion process; ${ }^{21}$ (v) firm management acts to maximize shareholder wealth; (vi) there is perfect antidilution ${ }^{22}$ and bankruptcy protection; ${ }^{23}$ and (vii) the Modigliani-Miller theorem holds (i.e., the firm's value is independent of its capital structure).

In this highly simplified model, the corporate default risk premium $s$ (also called yield spread or credit spread) is a function of only three variables: (i) the volatility of the returns on the firm value $\sigma_{V}$ (or simply firm-value volatility), (ii) the quasi-debt ratio $d$ (a form of leverage ratio), ${ }^{24}$ and (iii) the remaining time to maturity of the bond $\tau$,

$$
s_{t}=f\left(d, \sigma_{V}, \tau\right)
$$

where $s_{t} \equiv y_{t}-r$ with $y_{t}$ being the yield to maturity of the risky zero-coupon bond and $r$ the (constant) risk-free interest rate.

Merton (1974) shows that $\partial s / \partial \sigma_{V}^{2}>0, \partial s / \partial d>0$, and $\partial s / \partial \tau<>0$, that is, the corporate default spread is an increasing function of firm-value volatility and leverage, which seems intuitive; however, it can be an increasing or decreasing function of remaining time to maturity, depending on leverage. The Merton model thus produces the classical hump-shaped "term structure of credit spreads" - a non-intuitive result but a fact often

\footnotetext{
${ }^{21} d V_{t} / V_{t}=\mu d t+\sigma_{V} d Z_{1, t}$, where $\mu$ is the instantaneous expected rate of return on the firm value, $\sigma_{V}^{2}$ is the instantaneous variance of the return on the firm value $V$ per unit of time (henceforth called "asset return volatility" or simply "firm-value volatility"), and $d Z_{1, t}=\varepsilon_{1} \sqrt{d t}$ is a standard Gauss-Wiener process.

${ }^{22}$ There are neither cash flow payouts, nor issues of any new type of security during the life of the bond, nor bankruptcy costs. This implies that default can only occur at maturity if the firm cannot meet the repayment of the face value of the bond.

${ }^{23}$ Firms cannot file for bankruptcy except when they are unable to make the required cash payments. In this case, the absolute priority rule cannot be violated: shareholders obtain a positive payoff only if the debt holders are fully reimbursed.

${ }^{24}$ The quasi-debt ratio is the ratio of the present value (discounted at the risk-free rate, whence "quasi") of the bond over the current value of the firm.
} 
found in actual data. ${ }^{25}$ This term structure of credit risk spread is downward sloping for high-leveraged firms (i.e., $d>1),{ }^{26}$ hump-shaped for medium-leveraged firms, and upward sloping for low-leveraged firms $(d<1)$. In other words, for firms with a leverage ratio $d>1$, an increase in time to maturity $\tau$ will lead to a declining default premium $(\partial s / \partial \tau<0)$; for intermediate leverage ratios ( $d$ between around 0.7 and 1$)$, the credit spread first rises and then falls as maturity increases; for low leverage ratios ( $d$ below about 0.7), the default premium increases with longer time to maturity. Before discussing the economic intuition of $\partial s / \partial \sigma_{V}^{2}>0$ and $\partial s / \partial d>0$, we extend the Merton model by introducing interest rate risk.

\section{B. Adding Stochastic Interest Rates: The Shimko, Tejima, and Van Deventer (1993) Model}

Shimko, Tejima, and Van Deventer (1993) proposed to extend the Merton model by relaxing the assumption of constant risk-free interest rates, letting interest rates be stochastic instead. They achieve this extension by integrating the Vasicek (1977) term-structure-of-interest-rates model into the Merton (1974): framework, thereby integrating interest rate risk into the pricing of credit risk.

The fundamental result of the model by Shimko, Tejima, and Van Deventer (1993) is that once (risk-free) interest rates are allowed to be stochastic, interest rate volatility $\sigma_{r}$ becomes an additional determinant of the corporate default premium $s$. They also confirm the importance of the three determinants found by Merton (1974): firm leverage $d$, firm-value volatility $\sigma_{V}$, and remaining time to maturity of the bond $\tau$. Strictly speaking, the corporate yield spread $s$ is also a function of the correlation $\rho$ between the stochastic factor of the firm-value process $V$ and the stochastic factor of the interest rate process $r$, and of $\alpha$, the speed of convergence of the risk-free rate $r$ to its long-run mean $\gamma \cdot{ }^{27}$ For the present empirical investigation, however, these two parameters are assumed to be constant over the sample period.

In summary, Shimko, Tejima, and Van Deventer (1993) find that the corporate default premium $s$ is essentially a function of four important determinants: (i) firm leverage

\footnotetext{
${ }^{25}$ Merton (1974, p. 456); see also Sarig and Warga (1989, p. 1356).

${ }^{26}$ A firm with $d>1$ is technically insolvent.

${ }^{27}$ Shimko, Tejima, and Van Deventer (1993) assume that the short-term risk-free interest rate follows a (stationary) Ornstein-Uhlenbeck process of the form $d r=\alpha(\gamma-r) d t+\sigma_{r} d Z_{2, t}$, where $\gamma$ is the long-run mean which the short-term interest rate $r$ is reverting to, $\alpha>0$ is the speed at which this convergence occurs, $\sigma_{r}$ is the instantaneous variance (volatility) of the interest rate, and $d Z_{1, t}=\varepsilon_{1} \sqrt{d t}$ is a (second) standard Gauss-Wiener process, whose correlation with the stochastic firm value factor, $d Z_{1, t}$, is equal to $\rho$, i.e., $d Z_{1, t} \cdot d Z_{2, t}=\rho d t$.
} 
(measured by the quasi-debt ratio $d$ ); (ii) firm-value volatility $\sigma_{V}$; (iii) remaining time to maturity of the bond $\tau$; and (iv) interest rate volatility $\sigma_{r}$,

$$
s_{t}=f\left(d, \sigma_{V}, \tau, \sigma_{r}\right) .^{28}
$$

What is the impact on the corporate credit spread $s$ of changes in these four determinants? Apart from identifying an additional determinant $\left(\sigma_{r}\right)$, the major difference of the model by Shimko, Tejima, and Van Deventer. compared to that by Merton is that the nonlinear impacts of these determinants on the spread are more complex. One can show that the spread $s$ is a positive function of firm leverage $d$ and firm-value volatility $\sigma_{V}$, but can be either an increasing or decreasing function of interest rate volatility $\sigma_{r}$ and remaining time to maturity $\tau$, depending on the size of $\alpha$ (the speed of convergence of the risk-free rate $r$ to its long-run mean $\gamma$ ), $\rho$, (the correlation between shocks to the firm-value returns and interest rate shocks), $\tau, \sigma_{r}, \sigma_{V}$, and $d .^{29}$ The economic intuition of these effects is as follows:

- $\quad$ Firm leverage: The higher a firm's debt in relation to the value of its assets $(d)$, other things equal, the lower its net worth and, hence, the closer it is to default (i.e., bankruptcy) at any given moment in time. To be compensated against the higher probability of default (and, hence, expected loss), investors will ask a higher default premium (i.e., spread).

- $\quad$ Firm-value volatility: The higher the day-to-day fluctuations in the value of the firm's assets $\left(\sigma_{V}\right)$, other things equal, the higher the probability that - purely by chance - the asset value is smaller than the value of the debt on the day the debt is due, that is, that the firm defaults. To be compensated against the resulting higher default probability and expected loss, investors will ask a higher spread.

- Interest rate volatility: The corporate spread can be an increasing or decreasing function of interest rate volatility $\sigma_{r}$, depending on the firm's leverage $d$, its asset volatility $\sigma_{V}$, the correlation between asset return shocks and interest rate shocks $\rho$, and the term structure of interest rates (represented by the parameters $\alpha, \tau$, and $\sigma_{r}$ ). However, Shimko, Tejima, and Van Deventer note that "the credit spread is an increasing function of [interest rate volatility] for reasonable parameter values." ${ }^{, 30}$ To find out whether this is the case in our data sample, we

\footnotetext{
${ }^{28}$ Strictly speaking, the corporate yield spread $s_{t}$ is also function of (i) the correlation $\rho$ between the stochastic factor $d Z_{1}$ of the firm value process $V$ and the stochastic factor $d Z_{2}$ of the interest rate process $r$, and (ii) $\alpha$, the speed of convergence of the risk-free rate $r$ to its long-run mean $\gamma$. For the present exercise, however, these two parameters are assumed to be constant over the sample period.

${ }^{29}$ Shimko, Tejima, and Van Deventer (1993) determine the signs of $\partial s / \partial d, \partial s / \partial \sigma_{V}, \partial s / \partial \tau$, and $\partial s / \partial \sigma_{r}$ through simulations.

${ }^{30}$ (1993, p. 59).
} 
proceed as follows. First, we estimate the parameter values of $\alpha$ and $\rho$ implied by our data. ${ }^{31}$ Then, we simulate the impact of changes in $\sigma_{r}$ on $s$ for various combinations of sample values for $d, \sigma_{V}$, and $\tau$ (Table 5). The simulations show that for all combinations of sample values for $d, \sigma_{V}$, and $\tau$, the corporate spread either stays constant (for small $d, \sigma_{V}$, or $\tau$ ) or increases as interest rate volatility rises (i.e., $\left.\partial s / \partial \sigma_{r} \geq 0\right)$. Moreover, the stronger the impact of $\sigma_{r}$ on $s$, the higher leverage $d$. To control for this dependence, we will also include the interaction term $\sigma_{r} d$ in the (linearized) estimating equation; ${ }^{32}$ we expect its coefficient to be positive.

- $\quad$ Time to maturity: The corporate default spread can also be an increasing or decreasing function of remaining time to maturity $\tau$, depending on the same parameters as the impact of changes in interest rate volatility. More precisely, the Shimko, Tejima, and Van Deventer model produces a term structure of credit spreads that is similar to the one obtained in the Merton model, except that now it is not only the result of the dependence on leverage $d$ but also $\sigma_{V}$ : for small values of $d$ or $\sigma_{V}$, the spread increases when time to maturity $\tau$ lengthens; for intermediate values of $d$ or $\sigma_{V}$, the spread first increases sharply, then reaches a maximum, and finally declines gradually as $\tau$ increases; for high $d$ or $\sigma_{V}$, the spread declines as maturity increases. The economic intuition behind this theoretical result is as follows: if there is only a short time to go before maturity and leverage or, if firm-value volatility is high, the risk of default (and, hence, the spread) is high; the more time there is to go before maturity, the more opportunities the firm with the same leverage (or asset return volatility) will have to increase earnings and reduce leverage and, hence, the lower its default risk and spread. As before with $\sigma_{r}$, we run simulations to check whether the spectrum of values for $d, \sigma_{V}$, and $\tau$ in our sample produces such a complex term structure of credit spread or whether it is simpler. The simulations show again a strong dependence of $\partial s / \partial \tau$ on leverage $d:$ at the mean values of $\sigma_{V}(=23.4$ percent $)$ and $\sigma_{r}(=1.0$ percent $)$, the spread increases with maturity for values of $d$ between 0.1 and about 0.7 ; it first increases and then decreases with maturity for

\footnotetext{
${ }^{31}$ We obtain $\alpha=0.70$ and $\rho=0 . \alpha$ is obtained by estimating equation (30) in Vasicek (1977, p. 187), applied to our proxy for the short-term interest rate (three-month Bankers' acceptance rate, see Table 4) during January 1996-May 2003. To estimate $\rho$, we calculate the correlations between first differences in the short-term interest rate and firm-value returns for each of the nine firms in the sample; $\rho$ is significantly negative $(-0.42)$ for IPL1 and significantly positive $(0.33)$ for HAR1 but insignificantly different from zero for the seven other firms; hence, we assume $\rho=0$ in our sample.

${ }^{32} \partial s / \partial \sigma_{r}$ is also a positive function of maturity $\tau$ and firm-value volatility $\sigma_{V}$, but less pronouncedly over the range of values available in our sample. Thus, we do not include corresponding interaction terms to keep the empirical model as simple as possible and because of potential multicollinearity problems.
} 
$d$ between about 0.7 and 0.85 ; and it decreases with maturity for $d$ above $0.85 .{ }^{33}$ To control for this dependence in the simplest possible way, we also include the interaction term $\tau d$ in the linearized estimating equation, along with maturity $\tau$. We expect the coefficient of maturity alone to be positive and the one of the interaction term to be negative.

\section{Adding Sovereign Risk}

The central argument in this paper is that in an emerging market context, sovereign (default or credit) risk has to be factored into the corporate default premium equation as an additional determinant. All structural models of corporate credit risk pricing implicitly assume that government bonds are risk-free, i.e., that sovereign risk is absent. As these models are implicitly placed in a context of a AAA-rated country (typically the United States), this assumption seems justified. In analyzing emerging bond markets, however, the "zero-sovereign-risk" assumption has to be relaxed. In the international rating business, the importance of sovereign risk for the pricing of all corporate obligations has given rise to the concept of the sovereign ceiling, the rule that the rating of a corporate debt obligation (in foreign- but also domestic-currency terms) can usually be at most as high as the rating of government obligations.

What is the economic rationale for sovereign risk to be a determinant of corporate default risk in domestic-currency terms? Unlike in foreign-currency obligations where the influence of sovereign risk is essentially due to direct sovereign intervention (or transfer) risk, ${ }^{34}$ the impact of sovereign risk in domestic-currency obligations is more indirect. When a sovereign is in distress or default, economic and business conditions are likely to be hostile for most firms: the economy will likely be contracting, the currency depreciating, taxes increasing, public services deteriorating, inflation escalating, and interest rates soaring, and bank deposits may be frozen. In particular, the banking sector is more likely than any other industry to be directly or indirectly affected by a sovereign in payment problems. The banks' vulnerability is due to their high leverage (compared to other corporates), their volatile valuation of assets and liabilities in a crisis, their dependence on depositor confidence, and their typically large direct exposure to the sovereign. As a result, default risk of any firm is likely to be a positive function of sovereign risk. We will call this type of risk indirect sovereign risk. An interesting observation in this context is that Elton and others (2001) find that - even in the United States - corporate default premia incorporate a significant risk premium because a large part of the risk in corporate bonds is systemic rather than diversifiable. One could argue that in emerging markets, a major source of systemic risk is (indirect) sovereign risk, as measured by the yield spread of government bonds over comparable risk-free rates (i.e., the sovereign default premium).

\footnotetext{
${ }^{33}$ There is also a small positive dependence of $\partial s / \partial \tau$ on firm-value volatility $\sigma_{V}$ over the range of sample values. However, to keep the empirical model tractable, we refrain from including $\sigma_{V} \tau$ as an additional interaction term.

${ }^{34}$ See section I.B for a discussion of these concepts.
} 
Let us formalize these considerations in a simple framework. Recall that the corporate default premium (or spread) on a firm bond is essentially a compensation that an investor requires for the expected loss rate on that investment. The expected loss rate $(E L)$ is the product of the probability of default $(P D)$ times the loss-given-default rate $(L G D)$, that is, $E L=P D \cdot L G D$. Assuming for simplicity that (i) $L G D$ is equal to one (i.e., when the firm defaults, the entire investment is lost), (ii) investors are risk-neutral, and (iii) we consider only one-period bonds (i.e., there is no term-structure of default risk), the expected loss rate becomes equal to the probability of default $(E L=P D)$ and the corporate spread is only function of the company's probability of default, $s=f(P D)$.

Now, let us have a closer look at the firm's probability of default, $P D$, in the presence of sovereign risk. Using simple probability theory and acknowledging that a firm's default probability is dependent on the sovereign's probability of default, one can show that the following probabilistic statement holds:

$$
\begin{aligned}
P(F) & =P\left(F \cap S^{c}\right)+P(F \cap S) \\
& =P\left(S^{c}\right) \cdot P\left(F / S^{c}\right)+P(S) \cdot P(F / S) \\
& =P\left(F / S^{c}\right)+P(S)\left[P(F / S)-P\left(F / S^{c}\right)\right]
\end{aligned}
$$

where the different events are defined as follows:

(i) event $F$ : firm $i$ defaults,

(ii) event $S$ : the sovereign where firm $i$ is located defaults,

(iii) event $S^{c}$ (= complement of event $S$ ): the sovereign does not default.

Inspecting equation (3), we see that the probability of default of the firm, $P(F)=P D$, is the result of a combination of three other probabilities:

(i) $P\left(F / S^{c}\right)$ is the probability that the firm defaults given that the sovereign does not default. We can interpret this probability as the firm's default probability in "normal" times, as opposed to a "(debt) crisis" period. We call this probability the stand-alone default probability of the firm;

(ii) $P(S)$ is the default probability of the sovereign (sovereign risk);

(iii) $P(F / S)$ is the probability that the firm defaults given that the sovereign has defaulted. We can interpret this as the probability that the sovereign "forces" the firm - which would not otherwise default — into default. In other words, $P(F / S)$ can be interpreted as "direct sovereign intervention (or transfer) 
risk" in foreign-currency obligations, or what we have called "indirect sovereign risk" in domestic-currency obligations. ${ }^{35}$

In terms of credit ratings (which are nothing other than estimates of default probabilities), the four probabilities $P(F), P\left(F / S^{c}\right), P(S)$, and $P(F / S)$ have direct correspondents. In Moody's case, for instance, a bank's "domestic currency issuer rating" would correspond to $P(F)$, which itself can be interpreted as the result of the combination of its "bank financial strength rating," $P\left(F / S^{c}\right)$, of the "domestic currency issuer rating" of its sovereign of incorporation (or location), $P(S)$, and of the indirect sovereign risk applicable in its case, $P(F / S)$.

Examining a few boundary cases, we realize that equation (3) makes intuitive sense. When the sovereign default probability is zero, the firm's default probability reduces to its stand-alone default probability: $P(F)=P\left(F / S^{c}\right)$. As the sovereign default probability rises and approaches 100 percent $(P(S)=1)$, the importance of stand-alone default risk $\left(P\left(F / S^{c}\right)\right)$ vanishes compared to direct $(P(S))$ and indirect sovereign risk $(P(F / S)$ ); at the limit (when $P(S)=1$ ), the firm's default probability reduces to indirect sovereign risk (or transfer risk in foreign-currency obligations), i.e., $P(F)=P(F / S)$. If the firm's stand-alone default probability were zero $\left(P\left(F / S^{c}\right)=0\right)$ but there is sovereign risk $(P(S)>0)$, the firm's default probability would be equal to the product of direct and indirect sovereign risk $(P(S) \cdot P(F / S))$; in this case, only if indirect sovereign risk (or transfer risk) were also equal to zero would the firm's (overall) default probability also be equal to zero $(P(F)=0)$. Finally, when there is direct sovereign risk $(P(S)>0)$ and when indirect sovereign risk (or transfer risk) is 100 percent $(P(F / S)=1)$, the firm's default probability equals

$$
P(F)=P(S)+[1-P(S)] \cdot P\left(F / S^{c}\right)
$$

This boundary case is the key to understand the concept of the sovereign ceiling:

Definition 1: In the context of a firm's default probability, its credit rating, or its credit spread, the phrase "the sovereign ceiling applies" refers to the case when indirect sovereign risk (or transfer risk in foreign-currency obligations) is 100 percent, that is, when $P(F / S)=1$.

\footnotetext{
${ }^{35}$ In order to make equation (3) economically meaningful, the restriction that $P(F / S) \geq P\left(F / S^{c}\right)$ is required: the probability that the firm defaults given that the sovereign has defaulted is at least as high as the probability that the firm defaults given that the sovereign has not defaulted.
} 
Whenever indirect sovereign risk (or transfer risk) equals 100 percent, equation (4) implies that the firm's (overall) default probability $P(F)$ will always be at least as high as the default probability of its sovereign, $P(S)$, independently of how low its stand-alone default probability $P\left(F / S^{c}\right)$. In other words, when indirect sovereign risk (transfer risk) is 100 percent, the sovereign default probability (and, hence, the sovereign spread) acts as a floor to the firm's default probability (and its spread). In terms of credit ratings (where low default probabilities are mapped into high ratings, and high default probabilities into low ratings), this floor translates into a ceiling, hence the concept of sovereign ceiling. When indirect sovereign (or transfer) risk is smaller than 100 percent $(P(F / S)<1)$, the firm's overall default probability (spread) can be lower than the sovereign's default probability (spread) if its stand-alone default probability is sufficiently small.

To test whether the sovereign ceiling applies in our rand-denominated corporate spreads data, we resort to a result obtained by Durbin and $\mathrm{Ng}$ (2005). In a simple theoretical model similar to the framework used in this section, Durbin and $\mathrm{Ng}(2005)$ show that 100 percent transfer risk (i.e., indirect sovereign risk in domestic-currency obligations) implies that a one-percent increase in the government spread should be associated with an increase in the firm spread of at least one percent. In other words, in a regression of corporate spread changes on corresponding sovereign spread changes, 100 percent indirect sovereign risk implies that the beta-coefficient should be greater than or equal to one. In the logic of their model, the size of this estimated coefficient can be interpreted as the market's appreciation of indirect sovereign risk: a coefficient that is larger than one would imply that the market factors in an indirect sovereign risk of 100 percent (i.e., whenever the government defaults, the prevailing economic conditions force the firms into default as well); a coefficient statistically smaller than one would imply that the market judges indirect sovereign risk to be less than 100 percent. It will be interesting to compare our own estimates for domestic-currency-denominated (i.e., rand) corporate bonds with the results obtained by Durbin and $\mathrm{Ng}$ (2005) for foreign-currencydenominated corporate bonds. They found, among other things, that the coefficient was significantly smaller than one for the low-risk country group of which South Africa was a part (together with Czech Republic, Korea, Mexico, and Thailand).

In light of these considerations, we add the sovereign default premium, or sovereign spread, $s_{t}^{\text {sov }}$ (in an admittedly ad-hoc fashion) to our estimating equation. $s_{t}^{s o v}$ is defined as

$$
s_{t}^{s o v} \equiv y_{t}^{s o v}-R_{t}
$$

with $y_{t}^{\text {sov }}$ the yield to maturity on the (risky) government discount bond and $R_{t}$ the yield to maturity on the risk-free discount bond with the same maturity. In section V, we first test whether the sovereign spread can be considered as an additional determinant of corporate credit spreads. We expect the associated coefficient $\left(\partial s / \partial s^{s o v}\right)$ to be positive, as increasing sovereign risk should be associated with higher corporate risk as well. Then, if the sovereign spread turns out to be a significant explanatory factor for corporate 
spreads, the size of the coefficient $\partial s / \partial s^{\text {sov }}$ will be a test of whether the sovereign ceiling applies or not: If $\partial s / \partial s^{\text {sov }} \geq 1$, the sovereign ceiling in spreads applies; $\partial s / \partial s^{\text {sov }}<1$, the sovereign ceiling does not apply.

\section{Other Potential Determinants}

Once the assumption of frictionless markets is relaxed and/or particular bond indenture provisions are allowed, other determinants of the corporate default premium have to be taken into account. These include differential taxation of corporate and risk-free bonds, differences in liquidity of corporate and risk-free bonds, business cycle (macroeconomic) conditions, temporary demand for and supply of bonds imbalances, and specific bond indenture provisions, such as call options embedded in corporate bonds or the presence of a sinking fund provision. ${ }^{36}$

Among all these factors, only potential differences in liquidity are controlled for explicitly in the present investigation. Liquidity refers to the ease with which a bond (issue) can be sold without a significant price discount. One might expect the risk-free bond issues to be larger and thus more liquid than the corporate issues, such that the liquidity premium on corporate bonds will be larger than the one on comparable risk-free bonds. As a result, we would expect that the higher the liquidity, $l$, of a given corporate bond relative to that of a comparable risk-free bond, the lower the corporate spread. Thus, we expect $\partial s / \partial l$ to be negative.

With the exception of short-run demand and supply imbalance, which have to be omitted for lack of appropriate data, all other factors are implicitly controlled for: taxation of bond returns (i.e., interest payments and capital gains) is the same for all types of bonds in South Africa (unlike in the United States); macroeconomic conditions will be controlled for insofar as they are reflected in sovereign spreads; embedded call options are controlled for by working with yields-to-next-call (instead of yield-to-maturity) for the one bond ${ }^{37}$ that contains such a call option, the eight other corporate bonds do not contain any such features; and sinking fund provisions are absent in all nine corporate bonds we analyze.

\section{E. Synthesis}

According to the theoretical framework laid out in this section, the corporate default premium is a function of (i) sovereign risk, (ii) leverage, (iii) firm-value volatility, (iv) interest rate volatility, (v) remaining time to maturity, and (vi) liquidity,

\footnotetext{
${ }^{36}$ These factors are dealt with in the literature on corporate default risk in mature markets, in particular the U.S. corporate bond market. See footnote 14 .

${ }^{37}$ NED1, see section IV.A.
} 


$$
s=f\left(\stackrel{+}{s_{t}^{s o v}}, \stackrel{+}{d}, \stackrel{+}{\sigma_{V}}, \sigma_{r},+/ \tau^{-}, \bar{l}\right) .
$$

The plus or minus signs on top of each of the right-hand-side variables indicate how each of these determinants is expected to influence the corporate default premium (or spread) according to the theory.

In section $\mathrm{V}$, we estimate a linearized version of equation (5). Motivated by the results of the Merton and Shimko, Tejima, and Van Deventer models, we will also consider two interaction terms: one between interest rate volatility and leverage $\left(\sigma_{r} d\right)$, and the other between maturity and leverage $(\tau d)$. These will help us to unambiguously determine the expected signs of the coefficients involving $\sigma_{r}$ and $\tau$ : we expect the coefficient of $\sigma_{r} d$ to be positive, as the impact of interest rate volatility on spreads appears to be increasing with leverage; the coefficient of $\sigma_{r}$ alone could be positive or insignificant because the spread (and hence the influence of any determinant) vanishes as leverage tends toward zero. The coefficient of $\tau d$, on the other hand, is expected to be negative, along with a positive coefficient for maturity $\tau$ alone because the spread increases with maturity when leverage is small, whereas it declines with maturity when leverage is high. Table 3 (Appendix III) summarizes the determinants (together with their interactions) and lists their expected impact on the corporate default spread.

\section{OPERATIONALIZATION OF VARIABLES AND DATA}

This section first discusses how the corporate default premium is calculated and how the firms to be studied are selected. It then presents a summary of how the explanatory variables (sovereign default premium and firm-specific determinants identified in section III) are operationalized. The data sources as well as the sample characteristics are also briefly summarized.

\section{A. Dependent Variable: How Is the Corporate Default Premium Measured?}

Before the corporate default premium (or spread) can be calculated, appropriate corporate and risk-free securities need to be identified. This task is complicated by the absence of corporate zero-coupon bonds and the fact that bonds issued by the South African government cannot be considered risk-free.

We circumvent the absence of corporate zero-coupon bonds by using coupon-paying bonds to calculate spreads. According to the Merton-Shimko framework, we should calculate the spread as the difference between the yield to maturity on a zero-coupon corporate bond (called corporate spot rate) and the yield to maturity on a zero-coupon risk-free bond of the same maturity (risk-free spot rate). ${ }^{38}$ However, we find that there are

\footnotetext{
${ }^{38}$ This way of calculating the spread, rather than as the difference between the yield to maturity on a coupon-paying corporate bond and the yield to maturity on a coupon-paying risk-free bond, is also stressed
} 
no zero-coupon bonds available for South African firms. An attempt to circumvent the nonexistence of firm discount bonds by estimating the spot rates - for instance, by the procedure suggested by Nelson and Siegel (1987) - fails owing to the lack of a sufficient number of outstanding bonds per firm. ${ }^{39}$ Given the impossibility of estimating spot rates, the next best alternative would be to work with spreads calculated as the difference between the yield to maturity of the coupon-paying firm bond and the yield to maturity of the risk-free bond with the same coupon and the same maturity. The problem is that such corresponding risk-free bonds generally do not exist because the corporate default premium is also reflected in the size of the coupon so that the risk-free coupon bond with a similar maturity tends to have a lower coupon. Again, estimating yields to maturity of equivalent risk-free coupon bonds is rendered impossible by the absence of appropriate risk-free zero-coupon bonds. ${ }^{40}$ Therefore, our second best (or third best, actually) strategy to compute the corporate yield spreads is to take the yield to maturity of a given corporate bond and to subtract the yield to maturity of a risk-free bond that has a maturity and coupon amount as close as possible to that of the corporate bond. As a result, the spreads we calculate will fail to completely isolate the pure default premium. That is, due to slightly different maturities and coupon sizes, they will also include some term structure effects, as is the case in many other empirical investigations of credit spreads (see Durbin and Ng, 2005; Kamin and Von Kleist, 1999; Eichengreen and Mody, 1998; Larrain, Reisen, and von Maltzan, 1997; or Edwards, 1986).

The second issue - that South African government bonds cannot be considered risk-free ${ }^{41}$ - is dealt with by taking rand-denominated bonds issued by supranational organizations as our risk-free benchmark instruments. As we are interested in isolating the pure default premium, the risk-free bonds should be denominated in the same currency and should be issued in the same jurisdiction as the corporate bonds. This poses a problem because no South African companies issue bonds abroad in U.S. dollars, nor do riskless borrowers issue ZAR- (i.e., rand-) denominated bonds onshore (i.e., in Johannesburg). However, triple-A-rated supranational organizations like the European Investment Bank (EIB), the International Bank for Reconstruction and Development

by Elton and others (2001, pp. 251-52). They give three reasons for this argument: (i) arbitrage arguments hold with spot rates, not with yield to maturity on coupon bonds; (ii) yield to maturity depends on coupon; so if yield to maturity is used to define the spread, the spread will depend on the amount of the coupon; and (iii) calculating the spread as the difference in yield to maturity on coupon-paying bonds with the same maturity means that one is comparing bonds with different duration and convexity.

${ }^{39}$ Most South African companies have only one or two bonds outstanding.

${ }^{40}$ Athanassakos and Carayannopoulos (2001) suggest a procedure to construct the equivalent risk-free bonds using the coupon strips of U.S. treasury bonds (the risk-free bonds in their study). The problem with this procedure is that while our corporate bonds are of rather medium-term maturity, the risk-free zerocoupon bonds available to us (see next section) are only of very long maturities (2017 to 2029), so that it would be impossible to estimate the shorter end of the yield curves with any degree of accuracy.

${ }^{41}$ At the end of our sample period (May 2003), the Republic of South Africa's foreign currency debt was rated BBB by Standard \& Poor's (S\&P) and Baa2 by Moody's (i.e., the same rating); local currency debt was rated A by S\&P and A2 by Moody's. See Table 2 in Appendix III for the history of South Africa's ratings by the two rating agencies. 
(IBRD, usually known as the World Bank), and the European Bank for Reconstruction and Development (EBRD) are issuing ZAR-denominated bonds in offshore markets. In the absence of more appropriate alternatives, we will calculate the corporate spreads using the ZAR-denominated corporate bonds traded on the Bond Exchange of South Africa and these ZAR-denominated "supranational" bonds traded in offshore markets as our risk-free benchmarks. As a result, the calculated spreads will include a jurisdiction premium (Box 1). However, the presence of this jurisdiction premium in our measure of spreads should not bias the results because the jurisdiction premium very likely remained constant over the sample period (July 2000-May 2003) as there were no significant changes in the legal environment or the capital control regime.

Once these two issues are clarified, we start collecting end-month yield to maturity data for corporate and supranational bonds from Thomson Financial Datastream (DS) and BESA. We have to resort to both sources because DS contains no data for ZAR-denominated South African corporate bonds prior to August 28, 2000, while BESA contains no data on the supranational bonds that we have selected as risk-free benchmarks. Thus, for the period starting on August 28, 2000, we gather the yields for all South African firm bonds from DS. For the period preceding this date, we take the yields for these bonds from the BESA database. ${ }^{42}$ For the risk-free supranational bonds, all yield data is from DS. ${ }^{43}$

Next, we clear from our database potential anomalies or data that might bias the results of our econometric estimation. First, we drop all public companies (known as parastatals) from the sample because they are regarded as belonging to the same risk class as the sovereign, the Republic of South Africa (RSA). Second, for some corporates we eliminate outlier data due to inconsistent price or yield to maturity quotes at certain points in time. Third, we only take the bonds of those firms whose shares are listed on the Johannesburg Stock Exchange (JSE) because our empirical investigation requires stock price data. Fourth, we eliminate all floating rate bonds as they are priced differently. And fifth, we work with only one bond per firm to facilitate the empirical analysis and interpretation of the results. ${ }^{44}$ If a firm has more than one bond outstanding, we select the more liquid one, ${ }^{45}$ if several bonds display similar liquidity, we chose the one with the longer time series available.

\footnotetext{
${ }^{42}$ Data have been purchased from BESA. At BESA, bonds are quoted and traded in yield. Bond Exchange of South Africa (2003) describes how daily bond yields are determined. Bond Exchange of South Africa (1997) lays out how yields are converted into prices.

${ }^{43}$ Since DS contains annualized yields compounded annually while BESA lists annualized yields compounded semi-annually, the latter are converted to an annual-compounding basis by applying the formula $y_{a}=100\left[\left(1+y_{s} / 200\right)^{2}-1\right]$, where $y_{s}$ stands for "annualized yield (in percent) compounded semiannually" while $y_{a}$ stands for "annualized yield (in percent) compounded annually."

${ }^{44}$ An alternative would be to restrict the coefficient of each explanatory variable to be the same across different bonds of one firm in the subsequent regression analysis. However, such restrictions would unduly complicate the analysis.

${ }^{45}$ Liquidity is measured by the trading volume.
} 
After this elimination procedure, we end up with nine corporate bonds issued by five banking and four industrial firms. The nine firms, their bonds, the bonds' main features, the corresponding risk-free benchmark bonds (i.e., supranational bonds), and the RSA bonds that will be used to calculate the comparable sovereign default premia (see section IV.B) are summarized in Table 1 (Appendix III). For instance, "HARMONY GOLD 200113 percent 14/06/06 HAR1" means that Harmony Gold issued a bond in 2001 (code: HAR1) that pays a 13 percent coupon and matures on June 14, 2006. Seven of the nine bonds have a fixed coupon rate and a fixed maturity date. The remaining two - NED1 and SBK1 - have a fixed coupon rate until the date of exercise of the (first) call option. For these two bonds, the BESA database reports "yields to next call" instead of "yields to maturity," which we use for our analysis. Because of anomalous price behavior of some bonds after the penultimate coupon payment, we only use yield data series up to the date of the penultimate coupon payment for both corporate and risk-free bonds. Hence, the maximum data range of corporate and corresponding risk-free yield series extends from May 20, 1998 (starting date of the risk-free benchmark corresponding to IS59, i.e., EIB 199812 1/4 percent May 20, 2003) to June 4, 2003 (availability of BESA data). Panels 1 to 9 of Figure 1 (Appendix III) plot, for each bond, the daily yields to maturity of the corporate, the corresponding RSA ("sovereign"), and the corresponding risk-free (supranational) bond.

Finally, using EViews programming notation, the corporate credit spread, $S C O R$, is calculated as

$$
s_{t} \equiv S C O R ?=y ?-r f ?
$$

where $y$ is the yield to maturity (or redemption yield) of the corporate bond; $r f$ is the yield to maturity of the risk-free benchmark bond that corresponds as closely as possible to the corporate bond in terms of maturity and coupon ("the corresponding risk-free benchmark"); and "?" stands for each of the nine corporate bonds. We assign an identifier code to each of these bonds with the purpose of naming not only the dependent variable but also the explanatory variables associated with firm characteristics (see next section). These codes correspond to the BESA acronyms and are marked in bold in the third column in Table 1 (Appendix III). They are: AB01, ABL1, HAR1, IPL1, IS59, IV01, NED1, SFL1, and SBK1. Figure 2 (Appendix III) shows the resulting corporate spreads (or default premia) at the frequency (monthly) and over the sample period (July 2000May 2003) actually used in this study.

\section{B. Explanatory Variables}

\section{The Sovereign Default Premium}

To assess the impact of (pure) sovereign default risk on (pure) corporate default risk, it is important that, for each corporate bond considered, the calculated sovereign default premium corresponds exactly to the corporate default premium in terms of maturity and 
other bond-specific features. In particular, we should also use spot rates with the same maturity. However, since we had to use yields to maturity of coupon bonds for the calculation of the corporate default premia, we also use coupon bonds to calculate the corresponding sovereign default premia. For each corporate bond, we search for a coupon bond issued by the RSA that has maturity and coupon amount as close as possible to that of the corporate bond (and, hence, also to the risk-free bond selected in section IV). The penultimate column in Table 1 (Appendix III) lists the corresponding sovereign bonds selected.

Like for corporate bond yield data, we gather the yields to maturity of the corresponding sovereign bonds from the BESA database for the period up to July 2000, and from DS for the period thereafter. The corresponding sovereign default premium, or sovereign spread, $S S O V$, is calculated as

$$
s_{t}^{s o v} \equiv S S O V ?=s o v ?-r f ?
$$

where sov is the yield to maturity of the sovereign bond corresponding to each of the nine corporate bonds represented by "?", and $r f$ is the same yield to maturity of the corresponding risk-free benchmark bond as identified in section IV.A. Note that for sovereign countries holding a AAA rating, $S S O V$ would be zero because the sovereign bond is itself the risk-free benchmark asset, as implicitly assumed by Merton (1974) and later structural models.

A caveat: as is shown in Figure 3 (Appendix III), sovereign spreads are sometimes zero or negative, i.e., the risk-free (supranational) bond yields are higher than or equal to RSA bond yields for a comparable maturity. At least two important reasons could account for the relatively high yields of the supranational bonds: (i) for the latter, liquidity tends to dry up as they age; (ii) domestic investors are unable to buy eurobonds (lack of full financial integration of ZAR-denominated bond markets).

\section{Firm-Specific Determinants}

The empirical counterparts of the five theoretical determinants derived and discussed in section III are:

(i) Quasi-debt-to-firm-value (or leverage) ratio $\left(d_{t}\right)$ : D1?, D2?, or D3?;

(ii) Volatility of returns on the firm's value $\left(\sigma_{V}\right)$ : SV1000D?, SV12M?, or SV24M?;

(iii) Volatility of risk-free interest rate $\left(\sigma_{r}\right)$ : SIGSPOTM? or SIGRFM?;

(iv) Time to maturity $(\tau)$ : $M$ ?; and

(v) Liquidity, proxied by the trading volume ( $l$ ): TOVC? 
Table 5 (Appendix III) sums up the operationalization, measurement, and subcomponents of the five firm- or bond-specific determinants derived in section III. ${ }^{46}$

\section{Sample and Data}

Our "sample" consists of an unbalanced panel of monthly data for nine corporate bonds $(N=9)$ listed and traded on the BESA during the period July 2000 to May $2003 .^{47}$

"Sample" because the four industrial and five financial corporate issuers of these bonds essentially constitute the population of South African firms with bonds outstanding. The beginning of the sample (July 2000) is constrained by the availability of BESA data on our liquidity proxy (trading volume, $T O V C$ ). Observations are always as of end-month. The time-series dimension, $T$, of the panel varies between 21 and 35 months, i.e., $21 \leq T \leq 35$. Data are from BESA, DS, and Bloomberg. Table 5 (Appendix III) reports the descriptive statistics of the major variables discussed in section IV.

\section{EMPIRICAL METHOdOLOGY AND RESUltS}

In this section, we empirically test the predictions of a linearized version of the theoretical framework set up in section III and summarized in equation (5). The focus of our attention is on whether the sovereign default premium is a significant determinant of corporate spreads, and if so, whether the associated coefficient is larger or smaller than one. A coefficient smaller than one would imply that the sovereign ceiling does not apply for the firm concerned; an estimated coefficient larger than or equal to one would mean that the sovereign ceiling applies for that firm.

\section{A. The Econometric Model: Fixed Effects with Different Slopes for Sovereign Risk}

The linearized version of equation (5) that we estimate takes the form of a fixed effects (FE) model: ${ }^{48}$

$$
S C O R_{i t}=\alpha_{i}+\beta_{i} S S O V_{i t}+\sum_{j=1}^{k} \gamma_{j} X_{j, i t}+\varepsilon_{i t} i=1,2, \ldots, N ; t=1,2, \ldots, T,
$$

where $S C O R_{i t}$ is the corporate spread of firm bond $i$ at end-month $t$, as defined in section IV.A; $S S O V_{i t}$ is the sovereign spread which best matches $S C O R_{i t}$ in terms of maturity and coupon amount (see section IV.B); $X_{1, i t}, \ldots, X_{k, i t}$ is the set of $k=7$ firm-specific

\footnotetext{
${ }^{46}$ A methodological note discussing in detail the operationalization and measurement of these determinants can be obtained from the authors upon request.

${ }^{47}$ As noted, if a firm has more than one bond outstanding, we select the one that is more liquid (as measured by our liquidity proxy $T O V C$ ); if several bonds display similar liquidity, we chose the one with the longer time series available.

${ }^{48}$ Sometimes also called "least squares dummy variable" (LSDV) or "covariance" model.
} 
control variables (including their interaction terms) defined in section III and operationalized in Table 4 (Appendix III), namely:

(i) Quasi-debt-to-firm-value (or leverage) ratio $\left(d_{t}=D 1 ?, D 2 ?\right.$, or $D 3$ ?);

(ii) Volatility of returns on the firm's value $\left(\sigma_{V}=S V 1000 D\right.$ ?, SV12M? or SV24M?);

(iii) Volatility of risk-free interest rate ( $\sigma_{r}=$ SIGSPOTM? or SIGRFM?);

(iv) Time to maturity ( $\tau=M$ ?);

(v) Liquidity, proxied by the trading volume ( $l=T O V C$ ?);

(vi) Interaction between maturity and leverage $\left(\tau \cdot d_{t}\right)$; and

(vii)Interaction between interest rate volatility and leverage $\left(\sigma_{r} \cdot d_{t}\right)$;

$\alpha_{i}$ denotes the (unobservable) firm-specific effect, assumed time-invariant in the present context ("fixed effect"); $\beta_{i}$ and $\gamma_{1}, \gamma_{2}, \ldots, \gamma_{7}$ are the coefficients to be estimated; and $\varepsilon_{i t}$ is a normally distributed error term with zero mean, $E\left(\varepsilon_{i t}\right)=0$.

Ideally, we would want to estimate the coefficients $\alpha_{i}$ and $\beta_{i}$ as well as separate $\gamma_{j}$-coefficients (i.e., $\gamma_{1, i}, \gamma_{2, i}, \ldots, \gamma_{7, i}$ for $i=1, \ldots, N$ ) in individual time-series regression for each of the $N=9$ firms. However, with $21 \leq T \leq 35$ observations per firm, it would be difficult to obtain efficient and unbiased estimates for the nine firm-specific coefficients. To reduce collinearity problems and increase the degrees of freedom and the efficiency of estimation, we pool the time series of our nine firm bonds together. However, pooling data amounts to imposing restrictions on the parameters. In a fully pooled model, for instance, we assume that the parameters $\alpha_{i}, \beta_{i}$, and $\gamma_{1, i}, \gamma_{2, i}, \ldots, \gamma_{7, i}$ are the same across all nine firms, i.e., that $\alpha_{i}=\alpha, \beta_{i}=\beta$, and $\gamma_{j, i}=\gamma_{j}$ for all $i=1, \ldots, N$ firms and $j=1, \ldots, k$ control variables. However, we can also have less restrictive pool specifications, like the one proposed in equation (6), where the intercepts $\alpha_{i}$ and the slope coefficients $\beta_{i}$ of our main variable of interest, $S S O V$, are allowed to vary across the nine firms. The specification of equation (6) is the outcome of the following tests.

\section{Tests for Pooling}

Since pooling amounts to applying (linear) restrictions on the coefficients, an F-test can be used, where a restricted model is compared to an unrestricted model. Following Hsiao (1986) and Baltagi (1995), we perform two tests of progressively less restrictive pool specifications. ${ }^{49}$ The two sets of null and alternative hypotheses are: ${ }^{50}$

\footnotetext{
${ }^{49}$ Hsiao (1986, pp. 12-18), and Baltagi (1995, pp. 50-54).

${ }^{50}$ These tests are also known as "analysis-of-covariance” tests; see Hsiao (1986, pp. 12-18).
} 
Test 1: $\mathrm{H}_{0}$ : same intercepts $\left(\alpha_{i}=\alpha\right)$ and slopes $\left(\beta_{i}=\beta, \gamma_{j, i}=\gamma_{j}\right.$ for all $j=1, \ldots, k)$ across all firms $i$ (i.e., a "fully pooled" model is appropriate), against $\mathrm{H}_{1}$ : different intercepts but same slopes (i.e., "fixed effects" (FE) is the appropriate model);

Test 2: $\mathrm{H}_{0}$ : different intercepts $\left(\alpha_{i}\right)$ but same slopes $\left(\beta_{i}=\beta, \gamma_{j, i}=\gamma_{j}\right.$ for all $j=1, \ldots, k)$ across all firms $i$ (i.e., FE model), against $\mathrm{H}_{1}$ : different intercepts $\left(\alpha_{i}\right)$ and slopes for sovereign risk $\left(\beta_{i}\right)$ but same slopes for the control variables $\left(\gamma_{j, i}=\gamma_{j}\right.$ for all $\left.j=1, \ldots, k\right)$ across all firms $i$ (i.e., FE with different slopes for sovereign risk (SSOV), equation 6);

Appendix II.A provides the details of these tests. As the calculated F-statistic $(F=3.16)$ of the first test is larger than the critical value at the one-percent level of significance, we reject the null hypothesis of same intercepts and slopes (fully pooled model) in favor of the FE model. Robustness tests with different measures for leverage (D2 and D3 instead of D1), firm-value volatility (SV12M and SV24M instead of SV1000D), and interest rate volatility (SIGMARF instead of SIGSPOTM) lead to the same conclusion. But does the FE model pass the test against a less restrictive model like the one of equation (6)?

In test 2, the null hypothesis of homogenous slopes but different intercepts (FE model) is also rejected, at the one-percent level, in favor of the alternative, FE with different slopes for $\operatorname{SSOV}$ (equation 6). As before, robustness tests with alternative measures for leverage (D2 and D3 instead of D1), firm-value volatility (SV12M and SV24M instead of $S V 1000 D)$, and interest rate volatility (SIGMARF instead of SIGSPOTM) do not alter the conclusion.

\section{Fixed or Random Effects?}

In contexts like this one, the question usually arises whether the individual specific effects should be assumed to be fixed (FE model) or random (random effects, RE, model). According to Baltagi (1995), the FE model is the appropriate specification if the analysis is focusing on a specific set of $N$ firms and the inference is restricted to the behavior of this set of firms. ${ }^{51}$ The RE model, on the other hand, is an appropriate specification if we are drawing $N$ individuals randomly from a large population and want to draw inferences about the entire population. In light of these arguments, an FE model is the proper specification in our case for two reasons. First, we only draw inferences about the nine South African (financial and industrial) corporates we analyze; we do not try to generalize our conclusions to a broader set of firms. Second, the nine firms analyzed constitute essentially the entire population of South African firms with bonds listed and traded at the local bond market (BESA).

\footnotetext{
${ }^{51}$ Baltagi (1995, p. 12).
} 
In addition, an RE specification would not be feasible in the context of our estimation problem because the RE estimator requires the number of cross-sections to be larger than the number of coefficients to be estimated. In our setup, the number of cross-sections $(N=9)$ is lower than the number of coefficients to be estimated $(k=17$, including the constant).

\section{B. Choosing the Appropriate Estimator and First Results}

Once the specification is chosen- equation (6): FE with different slopes for sovereign risk-we have to analyze the OLS regression residuals in order to make the necessary adjustments to the estimator. When we deal with combined cross-section and time-series data, we should suspect both cross-sectional heteroskedasticity and residual autocorrelation within a given cross-sectional unit to be present. In addition, we should test whether there is contemporaneous correlation between the error terms of the different cross-sections (firms). Contemporaneous cross-section correlation is likely because the nine firms are potentially exposed to the same shocks (e.g., changes in investors' risk appetite for, or sentiment towards, South African securities as an asset class). Even though heteroskedasticity, autocorrelation, and (contemporaneous) cross-section correlation do not destroy the consistency of the OLS estimator, OLS is no longer efficient (i.e., minimum-variance) and, hence, standard errors will be biased. ${ }^{52}$ Thus, hypothesis testing on the basis of inefficient estimators may be misleading. Fortunately, some form of feasible generalized least squares (FGLS) estimators can correct for the lack of efficiency in these cases.

Before we proceed to test and correct for heteroskedasticity, autocorrelation, and crosssection correlation in our data sample, let us give - for the sake of completeness - the estimation results for (i) separate OLS regressions for all nine firms (slope-coefficients for SSOV only); (ii) pooled OLS; (iii) fixed effects (FE); and (iv) FE with different slopes for sovereign risk (equation 6) before correction. The first four columns of Table 6 (Appendix III) show the corresponding estimation results. In column 1, showing selected estimates from the nine individual firm regressions, most of the firm-specific $S S O V$-coefficients are significant and all of them are smaller than one. Most of the other determinants (not reported) however are not significant while the $\mathrm{R}^{2}$ are all very high-a typical indication of multicollinearity. In the pooled OLS regression (column 2), on the other hand, the (unique) $S S O V$-parameter is significantly larger than one, while it is significantly smaller than one in the FE regression (column 3); in the FE model with different slopes for SSOV (column 4), finally, the firm-specific coefficients are larger than one for four firms (ABSA Bank, African Bank, SASOL, and Standard Bank) and smaller for the five others (Harmony Gold, Imperial Group, ISCOR, Investec Bank, and Nedcor Bank). In all three pooled regressions, however, the very low Durbin-Watson statistic indicates serious misspecification (autocorrelation).

\footnotetext{
${ }^{52}$ Baltagi (1995, pp. 77-102).
} 
Tests and correction for cross-sectional heteroskedasticity. Appropriate heteroskedasticity tests in a panel context are the Lagrange multiplier $(L M)$ test and an approximate likelihood ratio $(L R)$ test. ${ }^{53}$ Both tests are applied to the OLS estimates of equation (6), i.e., the results reported in column 4 of Table 6 . The test details are given in Appendix II.-B. In both cases, the null hypothesis of homoskedasticity is rejected at the one-percent level of significance. Hence, we correct for heteroskedasticity using an appropriate FGLS estimator. Column 5 of Table 6 reports the results. The Durbin-Watson statistic has improved somewhat but the autocorrelation problems still persist.

Tests and correction for residual autocorrelation. We first use the $L M$ test for first-order serial correlation in a fixed effects model suggested by Baltagi (1995). ${ }^{54}$ Then, we also apply the Breusch-Godfrey $(B G)$ test $^{55}$ of higher-order autocorrelation as there are indications of potential higher-order autoregression in the estimated OLS residuals. Appendix II.C provides the details. The result of the $L M$ test suggests that there is (at least) first-order autocorrelation in the residuals of the OLS estimates reported in column 4 of Table 6. Subsequent experimentation, in the context of the $B G$ test, with the order of autoregression in the residuals leads us to conclude that there is evidence of second-order correlation in the error terms. Hence, we move to an FGLS estimator that allows for second-order autoregression in the error term in addition to the heteroskedastic-variance correction. The resulting estimates are shown in column 6 of Table 6. The Durbin-Watson statistic has now a value around two, indicating that autocorrelation should no longer be a problem. All goodness-of-fit measures improved substantially compared to the earlier specifications. ${ }^{56}$ The firm-specific sovereign risk coefficients (SSOV) also changed substantially, all of them being smaller than one now and - with the exception of the coefficient for the Harmony Gold bond HAR1 - all of them significant at least at the five-percent level. The fact that both autoregressive parameters, $A R(1)$ and $A R(2)$, are (highly) significant seems to justify the selection of a second-order autocorrelation correction.

Test for contemporaneous cross-section correlation. An appropriate test for contemporaneous cross-section correlation is the Breusch-Pagan $L M$ test. We test the null hypothesis of whether all the contemporaneous residual covariances are simultaneously equal to zero. We apply the test to the FGLS residuals obtained in the previous step (i.e., incorporating heteroskedasticity and second-order autocorrelation correction). The test details are explained in Appendix II.D. This time, the null hypothesis cannot be rejected at the five-percent level. Thus, seemingly-unrelated-regression- (SUR-) weighted FGLS is not necessary.

\footnotetext{
${ }^{53}$ See Greene (1993, pp. 449-50).

${ }^{54}$ See Baltagi (1995, p. 93).

${ }^{55}$ See Greene (1993, p. 426).

56 They are not fully comparable as the number of observations is now slightly lower (219 as compared to 237 in the previous specifications) due to the introduction of the AR(2) process in the error terms.
} 
As a result of this testing procedure, we choose FGLS corrected for heteroskedasticity and second order autocorrelation as our preferred estimator for equation (6). Column 6 in Table 6 reports the results. This choice is robust to the inclusion into the regression of our alternative measures for leverage ( $D 2$ and $D 3$ instead of $D 1)$, firm-value volatility (SV12M and SV24M instead of SV1000D), and interest rate volatility (SIGMARF instead of SIGSPOTM). We work with leverage D1, firm-value volatility $S V 1000 D$, and interest rate risk SIGSPOTM as our controls because we obtain the most significant results with them.

\section{A Robustness Check: Corporate Spreads in First Differences}

In their study of the impact of sovereign risk on foreign-currency-denominated corporate bond spreads, Durbin and $\mathrm{Ng}$ (2005) work with first differences of bond spreads instead of levels. ${ }^{57}$ To make our results comparable to theirs and to check the robustness of our level estimates, we also estimate a first difference equation. Taking first differences of equation (6), we obtain

$$
\Delta S C O R_{i t}=\beta_{i} \Delta S S O V_{i t}+\sum_{j=1}^{k} \gamma_{j} \Delta X_{j, i t}+u_{i t} i=1,2, \ldots, N ; t=1,2, \ldots, T,
$$

where $\Delta$ is the first-difference operator, $u_{i t}=\varepsilon_{i t}-\varepsilon_{i t-1}$, and all other components are as defined in equation (6). Note that the individual (or fixed) effects $\alpha_{i t}$ in equation (6) are eliminated by taking first-differences. As a result, estimation of equation (7) will be a regression through the origin (i.e., without intercept). Also note that we will have to expect (negative) autocorrelation in the error term.

Going through the same testing procedure as for the level equation, we accept the model of equation (7) as the appropriate pooled specification and we find that an FGLS estimator correcting for heteroskedasticity and first-order autocorrelation should be used. ${ }^{58}$ Column 7 in Table 6 reports the estimates. An essential first observation is that size and significance of the estimated coefficients are very similar to the estimates of the level equation (6).

\section{Discussion of Results}

Table 6 (Appendix III) summarizes the estimation results from the different specifications and estimators discussed in the previous three sections. Column 6 contains the final estimates of the level-equation (6), after correction for heteroskedasticity and serial correlation. To give an idea of the robustness of these estimates, column 7 also reports the estimated coefficients from the first-difference-equation (7).

\footnotetext{
${ }^{57}$ Their estimating equation does not include any firm-specific controls, however.

${ }^{58}$ The detailed test results are not reported. They are available from the authors upon request.
} 
Overall, we observe that the coefficients of most of the theoretical determinants (sovereign risk, firm-value volatility, leverage, ${ }^{59}$ and interest rate volatility ${ }^{60}$ ) have the expected sign and are statistically significant at conventional levels (Table 7). This result is in contrast with the mostly insignificant coefficients in the study by Durbin and $\mathrm{Ng}$ (2005). Only one control variable is clearly not significant: the monthly bond trading volume (TOVC), our proxy for a bond's liquidity. The fit of the model is surprisingly good: in the level equation, the adjusted R-squared is 96 percent, that is, 96 percent of the variation in corporate spreads is accounted for by the variation in the explanatory variables (and fixed effects), while the standard error of the model is 0.001 , that is, 10 basis points. In the first-difference equation, the adjusted R-squared is 75 percent with a similar standard error of 10 basis points.

Sovereign risk (SSOV) turns out to be a highly significant determinant of corporate spreads in most cases. In the level regression, the sovereign risk coefficient of only one firm - Harmony Gold (HAR1) — is marginally not significant at the five-percent level (although it is significant at the 10 percent level). In the first-difference equation, it is only the $S S O V$-coefficient of African Bank (ABL1) that is marginally not significant at the 5 percent level (but also significant at the 10 percent level). The size of these coefficients varies between 0.42 for Nedcor Bank (NED1) and 0.96 for ABSA Bank (AB01), implying that a 100 basis-point increase in the sovereign default premium is associated with an increase in corporate spreads of between 42 and 96 basis points.

Does the sovereign ceiling in spreads apply? According to the analytical framework of section III.C, the finding that there is a less than one-to-one correspondence between sovereign and corporate spreads for all firms (i.e., $\partial s_{t} / \partial s_{t}^{s o v}<1$ ) would be taken as evidence that the sovereign ceiling does not apply for these firms. ${ }^{61}$ But are the estimated $S S O V$-coefficients statistically different from one? We address this question formally by means of Wald tests (Appendix II.E). ${ }^{62}$

According to these Wald tests, there is evidence that the sovereign ceiling does not apply for the three large industrial companies. For Imperial Group (IPL1, a large, diversified, multinational firm) and ISCOR (IS59, the largest steel producer on the African continent), the null hypothesis that $\beta_{i}=1$ is rejected at the one-percent level in both the level and first-difference regressions. With $S S O V$-coefficients of 0.61 and 0.42 ,

\footnotetext{
${ }^{59}$ In the level equation only.

${ }^{60}$ Particularly in interaction with leverage, but less so on its own.

${ }^{61}$ Definition 1 in section III.C defines the concept of the sovereign ceiling.

${ }^{62}$ An equivalent test would involve testing the null of $\beta_{l}-1=0$ in a regression where the dependent variable is the spread of the firm over the sovereign bond yield (i.e., the corporate-over-sovereign premium $y_{i t}-S o v_{i t}$ ), while all RHS variables are as in equation (6). Formally, the equation to be estimated would be $\left(y_{i t}-\operatorname{sov}_{i t}\right)=\alpha_{i}+\left(\beta_{i}-1\right) S S O V_{i t}+\sum_{j=1}^{k} \gamma_{j} X_{j, i t}+\varepsilon_{i t}$. If the sovereign ceiling in terms of spreads does not apply, we would expect $\beta_{1}-1<0$. A disadvantage of using the transformed equation is that the theory laid out in section III does not tell us much about the determinants of the corporate-over-sovereign premium.
} 
respectively, there is clear evidence that the sovereign ceiling in spreads does not apply. For SASOL (SFL1), a large chemicals and fuels multinational, there is also some evidence, with a $S S O V$-coefficient (0.83) significantly smaller than one at the ninepercent level in the level equation and at the five-percent level in the first-difference equation. In terms of equations (3) and (4), the fact that the bond spreads of these companies are generally higher than comparable sovereign spreads (Figure 1, Appendix III) can therefore not be due to 100 percent indirect sovereign risk $P(F / S)$ (i.e., the application of the sovereign ceiling) but must be due to relatively high stand-alone default risk $P\left(F / S^{c}\right)$. Higher firm stand-alone risk, in turn, is accounted for by firmspecific variables.

This is good news for these three companies: some day in the future when financial markets judge them to be sufficiently strong (i.e., when their stand-alone default probability $P\left(F / S^{c}\right)$ is sufficiently low), their overall default probability $P(F)$ could fall below sovereign default risk $P(S)$. As a result, they might obtain (local currency) credit ratings that are lower than those of the South African government (i.e., they might "pierce the sovereign ceiling") and thus raise debt finance at lower cost than their government.

For the banks in the sample, the sovereign ceiling in spreads seems to apply in general. The sovereign risk coefficients of ABSA Bank (AB01; 0.96 and 0.98 in the level and first-difference equations, respectively) and African Bank (ABL1; 0.92 and 0.93, respectively) are statistically not different from one. The $S S O V$-coefficients of Standard Bank (SBK1; 0.89 and 0.92) and Investec Bank (IV01; 0.78 and 0.88) are also not significantly different from one in the first-difference equation. In the level equation, however, SBK1's coefficient is marginally smaller than one (at the 8 percent level) and IV01's significantly so (at the two-percent level). The sovereign risk coefficient of Nedcor Bank (NED1) is a surprising anomaly that would merit further investigation: at about 0.40 in both equations, it is the smallest $S S O V$-coefficient in the sample. ${ }^{63}$ In terms of the model in section III.C, $S S O V$-coefficients equal to one mean that bond markets judge indirect sovereign risk for these banks to be 100 percent (i.e., $P(F / S)=1$ ), which implies that the default probabilities $P(F)$ of these firms and, hence, spreads will be at least as high as those of the government (equation 4). Thus, the fact that these banks' spreads are generally higher than the comparable sovereign spreads (Figure 1, Appendix III), is due to the application of the sovereign ceiling rather than to higher stand-alone default risk $P\left(F / S^{c}\right)$. In other words, even if the stand-alone default probabilities $P\left(F / S^{c}\right)$ of these banks were much lower than the government's default probability $P(S)$, their overall default probabilities $P(F)$ and spreads would still be higher than those of their government because of the application of the sovereign ceiling. The finding that bond markets seem to price into spreads of banks a kind of sovereign

\footnotetext{
${ }^{63}$ This result might be due to an incomplete or wrong specification of the bond's indenture characteristics in DS and/or the BESA database.
} 
ceiling is consistent with rating agency practice of generally not rating financial institutions higher than their sovereign.

The following firm- or bond-specific factors are also found to significantly affect corporate default premia: ${ }^{64}$

- $\quad$ Firm-value volatility (SV1000D). An increase in the volatility (standard deviation) of returns on the firm's assets by 10 percentage points will increase corporate spreads by 48 basis points.

- $\quad$ Firm leverage, as measured by the quasi-debt-to-firm-value ratio (D1). The effect of a change in leverage on corporate spreads is reinforced by interest rate volatility, as expected; but it does not seem to depend on remaining time to maturity. This means that the higher interest rate risk is, the stronger the impact of a change in leverage on spreads. Quantitatively, if interest volatility were zero, an increase in a firm's leverage ratio by 0.5 - for instance, from 0.3 to 0.8 -would increase its spread by approximately 95 basis points; if interest rate risk is at its sample mean instead (1.01 percent per annum, see Table 5), the same 0.5 increase in the quasi-debt ratio would raise spreads by about 114 basis points.

- Interest rate volatility (SIGSPOTM). The volatility of the risk-free interest rate is a highly significant determinant of spreads in interaction with leverage, as expected; on its own, however, it is only marginally significant (at the seven percent level) and has the wrong sign. Considering the influence of interest rate volatility on its own as insignificant, we obtain the result implied by theory, namely that the impact of a change in this volatility on spreads depends positively on leverage and vanishes if leverage tends towards zero. Quantitatively, an increase in interest rate volatility by one-percentage point will increase the credit spread of our firms by about 19 basis points if their leverage stands at the sample mean (0.51); if leverage stood at the sample minimum (0.08), a one percentage point increase in interest volatility would increase corporate spreads by only three basis points. If we considered the estimated parameter of interest rate volatility in isolation as significant instead, the overall effect on spreads would still be positive for all leverage levels above 0.41 . Under this assumption, a change in volatility by one percentage point would increase spreads still by about four basis points if leverage were at the sample mean.

- $\quad$ Time to maturity (M). Remaining time to maturity is also a statistically significant determinant of corporate credit spreads, but seems to have the wrong (negative) sign. In addition, the interaction term with leverage is not significant. Quantitatively, an increase in remaining time to maturity by one year decreases corporate credit spreads by about 30 basis points. This result is less counterintuitive than it might appear at first: It suggests that during our sample

\footnotetext{
${ }^{64}$ The discussion focuses on the results from the level equation.
} 
period (July 2000-May 2003), the term structure of credit spreads of our nine firms has been downward sloping on average, independently of their leverage. According to the theoretical model, the credit spread term structure of a firm is downward sloping if the firm's leverage and/or its asset return volatility are relatively high. On the one hand, it is very well possible that the average term structure of credit risk of our nine firms has been downward sloping during July 2000-May 2003. On the other hand, this outcome might be spurious and due to pooling the data of the nine firms. In other words, if we had had sufficient data to run separate regressions for the nine firms, it is possible that the firms with relatively low leverage and asset volatility would have shown an upward-sloping term structure, whereas only those with relatively high leverage and asset volatility would have displayed a downward-sloping credit risk term structure.

Our proxy for a corporate bond's liquidity $(\boldsymbol{T O V C})$, the ZAR amount traded during the month, is not significant. ${ }^{65}$ This result suggests that TOVC is not a good proxy for liquidity. One potential reason is that $T O V C$ does not measure the liquidity relative to the risk-free bonds. We would ideally want to use the ratio of corporate bond turnover over risk-free bond turnover; but turnover data for the risk-free benchmark bonds were unfortunately not available. Another reason could be that we are faced with a timing problem: the dependent variable - the corporate spread - is observed on the last day of the month, whereas TOVC is the total amount traded during the month; that is, the latter might not be a good proxy for liquidity on the last day of the month.

Finally, a variance decomposition of the corporate default spreads confirms earlier findings that aggregate (systemic) factors appear to be much more important than firm-specific factors in determining these spreads (Table 8). Using the estimated parameters of the level and first-difference equations (Columns 6 and 7 in Table 6), we decompose the levels and changes of the corporate default premia into the four components (i) firm-specific factors, (ii) sovereign risk (the systemic factor), (iii) fixed effects (only for corporate spread levels), and (iv) the residuals. ${ }^{66}$ The data show that in both the level and the first-difference equations, the variation in sovereign risk (a systemic factor) explains about 12 to 13 times more of the total variation than the variation in the combined firm-specific factors derived from the contingent claims approach à la Merton and Shimko. In the level equation, 13 percent of the variation in corporate spreads is explained by the variation in sovereign risk, while only one percent of total variation is explained by the combined firm-specific factors. ${ }^{67}$ In the firstdifference equation, sovereign risk explains 61 percent of total variation, while firm-

\footnotetext{
${ }^{65}$ If we include the transformation $\ln (1+$ TOVC) instead given that the range of monthly turnover values is very large (between ZAR 0 and ZAR 4.08 billion), liquidity is significant but has the wrong (positive) sign, while all other coefficients remain essentially unchanged.

${ }^{66}$ See Appendix I.A for details of this decomposition.

${ }^{67}$ Not surprisingly for a level regression, the largest part of the variance ( 93 percent) is explained by the fixed effects, that is, the "between-variation" (i.e., the variation between the nine spread series) is much more important than the "within-variation" (i.e., the variation within each of the nine spread series).
} 
specific factors explain only 5 percent, with 34 percent of total variation remaining unexplained.

\section{Summary AND CONCLUSIONS}

The purpose of this paper is twofold. Using South Africa as a case study, it analyzes and quantifies the importance of sovereign risk in determining corporate default premia (yield spreads), after controlling for firm-specific determinants. Second, it investigates the extent to which the practice by rating agencies and internationally active banks of imposing a rating ceiling (country or sovereign ceiling) on subsovereign bond issues is reflected in market prices of local-currency-denominated corporate debt.

The paper contributes to the literature in at least four dimensions: (i) it is to our knowledge the first to directly investigate the impact of sovereign risk on local-currencydenominated corporate financing costs; (ii) it controls for firm-specific variables, contrary to existing empirical studies in the field; (iii) it uses an as-yet unexploited dataset from the BESA; and (iv) in light of the growing importance of local-currency bond issuances in emerging markets, it provides a methodology for further research on the impact of sovereign default risk on corporate spreads.

The firm-specific determinants of the corporate default premium are derived from the contingent claims approach. The contingent claims approach-pioneered by Merton (1974) and extended by, among others, Shimko, Tejima, and Van Deventer (1993) to include interest rate risk - shows that under certain conditions holding a risky firm's bond is equivalent to holding a portfolio consisting of a long position in a risk-free bond with similar characteristics and a short position in a put option on the assets of the same firm. Thus the famous Black-Scholes option pricing formula can be applied to determine the price of risky corporate debt. The corporate default premium (or yield spread) is then defined as the difference between the yield to maturity of the risky corporate bond and the yield to maturity of a risk-free bond with otherwise identical characteristics and its determinants are (i) the firm's leverage (measured by the quasi-debt to firm value ratio); (ii) firm-value volatility; (iii) risk-free interest rate volatility; ${ }^{68}$ and (iv) remaining time to maturity of the bond. To these four, differences in liquidity of corporate versus risk-free bonds are added as an important empirical determinant.

The central argument in the paper is that in an emerging market context sovereign default risk has to be factored into the corporate default premium equation as an additionalsystemic - determinant and that the size of the elasticity of corporate default premia with respect to sovereign default premia contains information about whether the sovereign ceiling in corporate spreads applies. A simple theoretical framework is developed to show how direct and indirect sovereign risk can be thought to affect a company's probability of default. The term "the sovereign ceiling in the spread of a firm applies" is

\footnotetext{
${ }^{68}$ Strictly speaking, risk-free interest rate volatility is a systemic determinant (see next paragraph). However, we mention it here because it also derives from the contingent claims approach.
} 
defined as an instance where indirect sovereign risk is equal to 100 percent, meaning that whenever the sovereign defaults on its debt, the firm defaults on its debt as well. To test empirically whether the sovereign ceiling applies in the spreads of our sample firms, we use a result obtained by Durbin and $\mathrm{Ng}(2005)$. They show in a model that if the sovereign ceiling applies, the elasticity of corporate spreads with respect to sovereign spreads should be greater than or equal to one.

Based on this theoretical framework, we estimate the impact of sovereign risk and firmspecific variables on the corporate default premia of nine South African firms. We use monthly data on a panel of four industrial and five financial firms in South Africa during the period July 2000-May 2003. The main findings are:

(i) Sovereign risk appears to be the single most important determinant of corporate default premia in South Africa. For almost all firms analyzed, sovereign risk is statistically and economically the most important determinant of their credit spreads. Quantitatively, a 100-basis-point increase in sovereign yield spreads is associated with an increase in the firms' yield spreads of between about 40 and 100 basis points. In addition, a variance decomposition of the corporate default spreads shows that the variation in sovereign risk explains 13 percent of total variation in corporate spread levels and 61 percent of total variation in corporate spread changes (firstdifferences). That is, sovereign risk explains 12 to 13 times more than combined firm-specific factors derived from the contingent claims approach à la Merton and Shimko. This preponderance of the sovereign risk component is consistent with the dominance of systemic risk over idiosyncratic risk observed in many emerging market economies.

(ii) The sovereign ceiling (in local-currency terms) does not apply in the spreads of the four large multinational industrial companies in the sample, in the sense that the elasticity of their spreads with respect to sovereign spreads is significantly lower than one (between 0.42 and 0.83 ). In terms of the framework developed in section III.C, the fact that the bond spreads of these companies are generally higher than comparable sovereign spreads (Figure 1, Appendix III) can therefore not be due to 100 percent indirect sovereign risk (i.e., the application of the sovereign ceiling) but must be due to relatively high stand-alone firm default risk. Higher firm standalone risk, in turn, is accounted for by firm-specific variables.

(iii) Consistent with rating agency policy, the sovereign ceiling appears to apply in the spreads of four of the five financial companies, with elasticities that are statistically not different from one (between 0.78 and 0.98). In terms of the framework developed in section III.C, the fact that the yield spreads of these financial companies are generally higher than the comparable sovereign spreads (Figure 1, Appendix III) is likely to be due to the application of the sovereign ceiling rather than to higher stand-alone default risk. In other words, even if the stand-alone default probabilities of these banks were much lower than the government's default probability, their 
overall default probabilities - and hence spreads - would still be higher than those of their government because of the application of the sovereign ceiling. The finding that bond markets seem to price into spreads of banks a kind of sovereign ceiling is consistent with the rating agency practice of generally not rating financial institutions higher than their sovereign.

(iv) The firm-specific factors derived from the contingent claims approach (leverage, firm-value volatility, remaining time to maturity, and risk-free interest rate volatility) are also statistically significant determinants of corporate spreads, contrary to the findings by Durbin and $\mathrm{Ng}$ (2005). However, a variance decomposition reveals that they are relatively unimportant, at least at a monthly frequency, explaining together only about one percent of total variation in corporate spread levels and five percent of total variation in corporate spread changes.

Provided that these results can be generalized to other emerging markets (i.e., they are not specific to South Africa), they have important implications for economic policy. First, in light of the importance of sovereign risk in determining corporate credit spreads, macroeconomic policies oriented toward reducing sovereign default risk (see Peter, 2002) — and hence improving a government's credit rating — can result in a significant reduction in the cost of debt capital for corporate borrowers, which in turn can help stimulate investment and economic growth. Second, the preponderance of sovereign risk over idiosyncratic risk in emerging economies should be taken into account by the respective supervisory agencies when assessing risks in their financial systems (and, in particular, in the banking sector).

The methodology developed in this paper could be used by rating agencies and banks to strengthen their process of rating companies in emerging markets. In particular, internationally active banks might find the methodology useful to estimate probabilities of default $(P D)$ of corporate and bank exposures in emerging markets in the context of the internal ratings-based (IRB) approach of the new Basel Capital Accord ("Basel II"). ${ }^{69}$ The method is applicable to both local- and foreign-currency exposures, provided appropriate and reasonably liquid firm and sovereign bonds are available in the respective currencies. According to this methodology, the necessary ingredients to calculate a counterpart's $P D$ for a foreign-currency (FX) debt exposure would be: ${ }^{70}$ (i) the default probability associated with the counterpart's stand-alone FX rating, labeled $P\left(F / S^{c}\right) ;^{71}$ (ii) the sovereign default probability associated with the FX credit rating of the sovereign in which the counterpart is located, labeled $P(S)$; and (iii) the probability associated with direct sovereign intervention ("transfer risk"), labeled $P(F / S)$. An estimate of the latter — direct sovereign intervention (or transfer) risk — can be obtained by estimating the

\footnotetext{
${ }^{69}$ See Basel Committee on Banking Supervision (2004, pp. 55-56).

${ }^{70}$ The case of local-currency (namely South African rand) exposures is the object of this study.

${ }^{71}$ For details, see section III.C.
} 
elasticity of the counterpart's credit spreads with respect to the credit spreads of its sovereign of incorporation/location, controlling for firm-specific risk factors. If the estimated elasticity is significant and greater than or equal to $1, P(F / S)$ is equal to 1 ; if it is significant but smaller than 1 , it can be directly used as rough estimate of $P(F / S)$. The counterpart's overall $P D$ on the foreign-currency debt exposure is then given by equation (2): $P D=P\left(F / S^{c}\right)+P(S)\left[P(F / S)-P\left(F / S^{c}\right)\right]$.

The findings of the paper suggest some topics for further research. First, similar empirical studies of other emerging market economies could be conducted to find out whether the strong relationship between sovereign and corporate financing costs is specific to South Africa or a more general phenomenon. The generally strong relationship between corporate and sovereign credit ratings in emerging markets would suggest that it is a quite general phenomenon. Second, more theoretical work needs to be devoted to studying the interaction between corporate credit risk and sovereign (credit) risk, presumably in a general equilibrium framework. Existing theoretical models of corporate default risk (i.e., the contingent-claims approach) predict that-besides interest rate risk-firm-specific factors should drive corporate credit spreads. However, our results confirm for an emerging market what has been found by Collin-Dufresne, Goldstein, and Martin (2001) in the United States, namely that aggregate (systematic) factorssovereign risk in our case - appear to be much more important than firm-specific factors in determining corporate default spreads. Thus, they highlight an important shortcoming of the existing structural models of default risk. 


\section{Mathematical Appendix}

\section{A. Variance Decomposition of Corporate Default Premium}

Let us rewrite the level equation (6) as

$$
C S=F E+F S+S Y+R E
$$

whereby $\quad C S=S C O R_{i t}$ is the vector of corporate default premia

$F E=\alpha_{i}$ is the vector of (firm-specific) fixed effects

$S Y=\beta_{i} S S O V_{i t}$ is the vector of (systemic) sovereign risk premia

$F S=\sum_{j=1}^{k} \gamma_{j, i t} X_{j, i t}$ is the vector of firm-specific factors derived from the contingent claims approach, and

$R E=\varepsilon_{i t}$ is the vector of regression residuals.

Proposition: The variance decomposition of $C S$ in percent is given by

$$
1=\frac{\operatorname{Cov}(C S, F E)}{\operatorname{Var}(C S)}+\frac{\operatorname{Cov}(C S, S Y)}{\operatorname{Var}(C S)}+\frac{\operatorname{Cov}(C S, F S)}{\operatorname{Var}(C S)}+\frac{\operatorname{Cov}(C S, R E)}{\operatorname{Var}(C S)} \text {. }
$$

Proof: Apply the expectations operator to both sides of (A1):

$$
E(C S)=E(F E)+E(F S)+E(S Y)+E(R E) .
$$

Then, subtract (A3) on both sides of (A1):

$$
C S-E(C S)=[F E-E(F E)]+[F S-E(F S)]+[S Y-E(S Y)]+[R E-E(R E)] .
$$

Next, multiply both sides of (A4) by $[C S-E(C S)]$ and apply the expectations operator to both sides of (A4). Considering that $E\{[X-E(X)][Y-E(Y)]\}=\operatorname{Cov}(X, Y)$ and $E[X-E(X)]^{2}=\operatorname{Var}(X)$, we obtain

$$
\operatorname{Var}(C S)=\operatorname{Cov}(C S, F E)+\operatorname{Cov}(C S, S Y)+\operatorname{Cov}(C S, F S)+\operatorname{Cov}(C S, R E) .
$$

Dividing both sides of (A5) by $\operatorname{Var}(C S)$ yields (A2).

The decomposition of the corporate spread changes (equation 7) is analogous, except that there are no fixed effects.

\section{B. Numerical Procedure to Calculate Volatility of Firm Value}

First, we transform equation $\sigma_{E}=\sigma_{V} \frac{V \Phi\left(h_{1}\right)}{E}$ to $\sigma_{V}=\frac{\sigma_{E} E}{V \Phi\left(h_{1}\right)}$. Then, we calculate $\sigma_{V}$ for all firms over all months assuming $\sigma_{V}=\mathrm{SV} 12 \mathrm{M}$; we call this estimate $\mathrm{sv}_{\text {old }}$. Then, 
we use $\mathrm{sv}_{\text {old }}$ as an input in the first iteration, substituting $\mathrm{sv}_{\text {old }}$ for $\sigma_{V}$ on the RHS (i.e., inside $h_{1}$ ) of $\sigma_{V}=\frac{\sigma_{E} E}{V \Phi\left(h_{1}\right)}$. We call the resulting $\sigma_{V}$ of this first iteration $\mathrm{sv}_{\text {solution. For the }}$ second iteration, we use $\mathrm{sv}_{\text {solution }}$ as input into the equation, getting a new $\mathrm{sv}_{\text {solution. }}$ We repeat this procedure until the difference between two subsequent values for $\mathrm{sv}_{\text {solution }}$ becomes smaller than 0.000001. Convergence is achieved after seven iterations. 


\section{Econometric Tests}

\section{A. Tests for Pooling}

Following Hsiao (1986) and Baltagi (1995), we perform two F-tests in which we compare the sum of squared residuals of an unrestricted model (SSRU) to the sum of squared residuals of a restricted model $(S S R R) .{ }^{72}$ The test statistic is:

$$
F\left[\left(d f_{r}-d f_{u}\right), d f_{\mathrm{u}}\right]=\left[\frac{\frac{S S R R-S S R U}{d f_{r}-d f_{u}}}{\frac{S S R U}{d f_{u}}}\right],
$$

where $d f_{r}$ and $d f_{u}$ are the degrees of freedom of the restricted and the unrestricted model, respectively. ${ }^{73}$ Note that these tests are valid if the residuals $\varepsilon_{i t}$ are independently normally distributed over $i$ and $t$ with mean zero and variance $\sigma^{2}$. For this reason, the tests are executed using an FGLS estimator that corrects for (cross-section) heteroskedasticity and second-order autocorrelation (see Appendix II, sections B-D for the corresponding tests). Tables A2.1 to A2.3 summarize the results of the three tests explained in section V.A.

Test 1: Pooled OLS is the restricted model; fixed effects (FE) is the unrestricted model.

Table A2.1. F-Test: Pooled OLS vs. Fixed Effects

\begin{tabular}{|c|c|}
\hline \multicolumn{2}{|c|}{ Explanatory variables: SSOV? SV1000D?M? TOVC? D1? M?*D1? } \\
\hline SSRU FE (different intercepts but same slopes) & 0.000304 \\
\hline SSRR Pooled OLS (same slopes and intercepts) & 0.000342 \\
\hline \multicolumn{2}{|l|}{$\mathrm{N}=9, \mathrm{~T}_{\max }=35 ;$ number of pooled observations: 219} \\
\hline $\mathrm{df}_{\mathrm{u}}=219-\mathrm{N}-\mathrm{k}=219-9-8$ & 202 \\
\hline $\mathrm{df}_{\mathrm{r}}=219-\mathrm{k}-1=219-8-1$ & 210 \\
\hline F statistic & 3.16 \\
\hline Critical $F(8 ; 202)$ at 1 percent & 2.60 \\
\hline
\end{tabular}

Note: SSRs are obtained using FGLS and correcting for $A R(2)$ in error terms.

Test 2: FE is the restricted model; FE with different slopes for $S S O V$ (equation 6) is the unrestricted model.

\footnotetext{
${ }^{72}$ Hsiao (1986, pp. 12-18), and Baltagi (1995, pp. 50-54).

${ }^{73}$ Greene (1993, p. 468), provides an F-statistic based on the R-squared from the restricted and unrestricted regressions.
} 
Table A2.2. F-Test: Fixed Effects vs. Fixed Effects with different slopes for SSOV

Explanatory variables: SSOV? SV1000D?M? TOVC? D1? M?*D1?
SIGSPOTM? D1?*SIGSPOTM? (i.e., $\mathrm{k}=8$ )

SSRU FE with different slopes forSSOV(slopes for all other explanatory variables are the same)

SSSR FE (different intercepts but same slopes)

$\mathrm{N}=9, \mathrm{~T}_{\max }=35$; number of pooled observations: 219

$\mathrm{df}_{\mathrm{u}}=219-2^{*} \mathrm{~N}-(\mathrm{k}-1)=219-18-7$

$\mathrm{df}_{\mathrm{r}}=219-\mathrm{N}-\mathrm{k}=219-9-8$

F statistic Critical $F(8 ; 194)$ at 1 percent

Note: SSRs are obtained using FGLS and correcting for $\mathrm{AR}(2)$ in error terms.

\section{B. Heteroskedasticity Tests}

$\mathrm{H}_{0}$ : residual variances are homoskedastic (i.e., $s_{i}^{2}=s^{2}$ for all $i$ ); $\mathrm{H}_{1}$ : residual variances are heteroskedastic (i.e., $s_{i}^{2} \neq s^{2}$ for all $i$ ).

Lagrange Multiplier (LM) Test: Adapting Greene (1993, p. 450), to the case of an unbalanced panel, the $L M$ test statistic is

$$
L M=\frac{T_{i}}{2} \sum_{i=1}^{N}\left[\frac{s_{i}^{2}}{s^{2}}-1\right]^{2},
$$

where $T_{i}$ is the number of time-series observation for firm $i, N$ is the number of firms, $s_{i}^{2}$ is the residual variance of firm $i$, and $s^{2}=\sum_{i=1}^{N} \sum_{t=1}^{T_{i}} e_{i t}^{2} / \sum_{i=1}^{N} T_{i}$, i.e., the sum of squared residuals divided by the total number of observations. The $L M$ statistic follows a chi-squared distribution with $N-1$ degrees of freedom $(d f)$. Based on the specification of equation (6), the OLS results imply that $L M=73.99$, which is larger than critical chi-squared with $8 d f$ at the 1 percent level of significance (20.09), so $\mathrm{H}_{0}$ is rejected.

Approximate Likelihood Ratio (LR) Test: Adapting Greene (1993, p. 450), to the case of an unbalanced panel, the $L R$ test statistic is

$$
L R=\left(\sum_{i=1}^{N} T_{i}\right) \ln s^{2}-\sum_{i=1}^{N} T_{i} \ln s_{i}^{2},
$$

where the different parameters are the same as those for the $L M$ test statistic above, except that the residuals are computed using the maximum likelihood estimators. $L R$ follows a chi-squared with $N-1$ degrees of freedom. Based on the specification of 
equation (6), the OLS results imply that $L M=55.48$, which is larger than critical chi-squared with $8 d f$ at the 1 percent level (20.09), so $\mathrm{H}_{0}$ is rejected as well.

\section{Tests for Autocorrelation}

An LM test for First-Order Serial Correlation in a Fixed Effects Model: ${ }^{74}$ In this test, $\mathrm{H}_{0}$ : no autocorrelation (i.e., $\rho=0$ ) given that the individual effects are fixed parameters; against $\mathrm{H}_{1}$ : first-order autocorrelation (i.e., $\mathrm{AR}(1)$ ). The $L M$ test statistic is

$$
L M=\left[N T^{2} /(T-1)\right]\left(\mathbf{e}^{\prime} \mathbf{e}_{-\mathbf{1}} / \mathbf{e}^{\prime} \mathbf{e}\right)^{\mathbf{2}},
$$

where $N$ is the number of cross-sections $i, T$ is the average number of time series observations per firm $i$, and $\mathbf{e}$ is the vector of OLS residuals from equation (6). Under $\mathrm{H}_{0}, L M$ is asymptotically distributed (for large $T$ ) as chi-squared with $1 d f$. OLS applied to equation (6) yields $L M=74.68$, which is much larger than the critical chi-squared with $1 d f$ at the 1 percent level (6.63). We conclude that there is (at least) first-order serial correlation in the residuals.

Breusch-Godfrey (BG) Test of Higher-Order Autocorrelation: ${ }^{75} \mathrm{H}_{0}$ : no autocorrelation (i.e., $\rho=0$ ); against $\mathrm{H}_{1}$ : errors follow an autoregressive process of order $p$ (i.e., $\left.\varepsilon_{i t}=\mathrm{AR}(p)\right)$. The $B G$ test statistic is given by

$$
B G=(n-p) \mathrm{R}^{2},
$$

where $\mathrm{R}^{2}$ is the R-squared obtained by regressing the OLS residuals, $e_{i t}$, on all the explanatory variables, plus $e_{i t-1}, \ldots, e_{i t-p}$, and $n$ is the total number of observations in the regression. $B G$ follows asymptotically a chi-squared distribution with $p$ degrees of freedom. Testing for AR(2) in the OLS residuals of equation (6) results in $B G=109.82$, which is much larger than the critical chi-squared with $2 d f$ at the one-percent level (9.21). Experimenting with the value of $p$ shows that the test statistic reaches a peak at $p$ $=2$. We conclude that there is evidence of second-order correlation in the error terms.

\section{Test for Contemporaneous Cross-Section Correlation}

We use the Breusch-Pagan $L M$ test. ${ }^{76} \mathrm{H}_{0}$ : Off-diagonal elements of the residual variancecovariance matrix are zero (i.e., no contemporaneous cross-section correlation); $\mathrm{H}_{1}$ : Cross-section correlation is present. The $L M$ test statistic, adjusted for an unbalanced panel, is

$$
L M=\sum_{i=2}^{N} \sum_{j=1}^{i-1} T_{i j} r_{i j}^{2}
$$

\footnotetext{
${ }^{74}$ See Baltagi (1995, p. 93).

${ }^{75}$ See Greene (1993, p. 426).

${ }^{76}$ Greene (1993, p. 454).
} 
where $r_{i j}$ is $i j$ th residual correlation coefficient, and $T_{i j}$ is the number of observations used in the calculation of $i j$ th residual correlation coefficient. $L M$ follows a chi-squared distribution with $N(N-1) / 2$ degrees of freedom ( $N$ being the number of cross-sections). The correlations $r_{i j}$ are computed on the basis of the FGLS estimates correcting for heteroskedasticity and $2^{\text {nd }}$ order serial correlation. The calculated $L M$ statistic (48.08) is smaller than the critical chi-squared with $36 d f$ at the five-percent level, so we do not reject $\mathrm{H}_{0}$. Therefore, seemingly-unrelated-regression- (SUR-) weighted FGLS is not necessary.

\section{E. Wald-Tests: Does the Sovereign Ceiling Apply for the Nine Firms?}

Table A2.3. Wald-Tests of $\beta_{i}$

Null hypothesis: $\beta_{i}-1=0$

A) Level Equation (6)

\begin{tabular}{lrrrrr}
\hline Firm bond & $\beta_{i}-1$ & Std. Err. & Wald Chi-square & df & Prob. \\
\hline AB01 & -0.037 & 0.042 & 0.793 & 1 & 0.37 \\
ABL1 & -0.080 & 0.436 & 0.034 & 1 & 0.85 \\
HAR1 & -0.426 & 0.303 & 1.967 & 1 & 0.16 \\
IPL1 & -0.388 & 0.131 & 8.757 & 1 & 0.00 \\
IS59 & -0.581 & 0.203 & 8.196 & 1 & 0.00 \\
IV01 & -0.224 & 0.096 & 5.473 & 1 & 0.02 \\
NED1 & -0.595 & 0.106 & 31.812 & 1 & 0.00 \\
SFL1 & -0.166 & 0.099 & 2.828 & 1 & 0.09 \\
SBK1 & -0.106 & 0.061 & 3.047 & 1 & 0.08 \\
& & & & & \\
B) First Difference Equation & $(7)$ & & & \\
\hline AB01 & -0.022 & 0.042 & 0.280 & 1 & 0.60 \\
ABL1 & -0.069 & 0.501 & 0.019 & 1 & 0.89 \\
HAR1 & -0.398 & 0.271 & 2.161 & 1 & 0.14 \\
IPL1 & -0.449 & 0.143 & 9.803 & 1 & 0.00 \\
IS59 & -0.595 & 0.173 & 11.763 & 1 & 0.00 \\
IV01 & -0.120 & 0.117 & 1.054 & 1 & 0.30 \\
NED1 & -0.596 & 0.104 & 33.112 & 1 & 0.00 \\
SFL1 & -0.177 & 0.091 & 3.820 & 1 & 0.05 \\
SBK1 & -0.076 & 0.062 & 1.484 & 1 & 0.22 \\
\hline
\end{tabular}

Source: Authors' calculations 
Tables and Figures

Table 1. South African Corporate Bonds: Issuers, Main Features, and Corresponding Benchmark Instruments

\begin{tabular}{|c|c|c|c|c|c|c|c|c|}
\hline Firm & Activity & Firm Bond & $\begin{array}{c}\text { Principal } \\
\text { Amount } \\
\text { Outstanding } \\
\text { (ZAR million) } \\
77\end{array}$ & $\begin{array}{c}\text { Percent of } \\
\text { Debt Traded }^{78}\end{array}$ & Issue Date & $\begin{array}{c}\text { Risk-free } \\
\text { Benchmark }\end{array}$ & $\begin{array}{c}\text { Corresponding } \\
\text { RSA } \\
\text { Government } \\
\text { Bond }\end{array}$ & $\begin{array}{l}\text { Sample } \\
\text { Range }\end{array}$ \\
\hline ABSA Bank & Banking & $\begin{array}{l}\text { ABSABANK } \\
\text { LTD. } 200015 \% \\
01 / 03 / 05 \underline{\mathbf{A B 0 1}}\end{array}$ & 1250 & $\begin{array}{l}29 \% \\
\text { (Rest: AB02 } \\
\text { ZARm } 3100 \\
\text { since 22/3/02) }\end{array}$ & $01 / 03 / 00$ & $\begin{array}{l}\text { EIB } 1999 \\
13 \% \\
03 / 06 / 05\end{array}$ & $\begin{array}{l}\text { RSA } 198413 \% \\
\text { 15/07/05 R124 }\end{array}$ & $\begin{array}{l}\text { Jul } 00 \text { to } \\
\text { May } 03\end{array}$ \\
\hline African Bank & $\begin{array}{l}\text { Specialty \& } \\
\text { Other } \\
\text { Financial } \\
\text { Activities }\end{array}$ & $\begin{array}{l}\text { AFRICAN } \\
\text { BANK 2001 } 12 \\
1 / 2 \% 28 / 02 / 05 \\
\text { ABL1 } \\
\end{array}$ & 1000 & $100 \%$ & $12 / 10 / 01$ & $\begin{array}{l}\text { EIB } 1999 \\
13 \% \\
03 / 06 / 05\end{array}$ & $\begin{array}{l}\text { RSA } 198413 \% \\
15 / 07 / 05 \text { R124 }\end{array}$ & $\begin{array}{l}\text { Oct } 01 \text { to } \\
\text { May } 03\end{array}$ \\
\hline $\begin{array}{l}\text { Harmony } \\
\text { Gold }\end{array}$ & Mining & $\begin{array}{l}\text { HARMONY } \\
\text { GOLD } 2001 \text { 13\% } \\
\text { 14/06/06 HAR1 }\end{array}$ & 1200 & $100 \%$ & $11 / 06 / 01$ & $\begin{array}{l}\text { EIB 2001 } \\
11 \% \\
28 / 12 / 06 \\
\end{array}$ & $\begin{array}{l}\text { RSA } 1996 \\
12.50 \% \\
21 / 12 / 06 \text { R184 } \\
\end{array}$ & $\begin{array}{l}\text { Jun } 01 \text { to } \\
\text { May } 03\end{array}$ \\
\hline $\begin{array}{l}\text { Imperial } \\
\text { Group (PTY) }\end{array}$ & $\begin{array}{l}\text { Diversified } \\
\text { Industry }\end{array}$ & $\begin{array}{l}\text { IMPERIAL } \\
\text { GP.(PTY.) } 2001 \\
11 \% 14 / 03 / 06 \\
\text { IPL1 }\end{array}$ & 800 & $\begin{array}{l}50 \% \\
\text { (Rest: IPL2 } \\
\text { ZARm 800) }\end{array}$ & $14 / 09 / 01$ & $\begin{array}{l}\text { EIB 2001 } \\
11 \% \\
28 / 12 / 06\end{array}$ & $\begin{array}{l}\text { RSA } 1996 \\
12.50 \% \\
21 / 12 / 06 \text { R184 }\end{array}$ & $\begin{array}{l}\text { Sep } 01 \text { to } \\
\text { May } 03\end{array}$ \\
\hline ISCOR & $\begin{array}{l}\text { Steel \& } \\
\text { Other Metals }\end{array}$ & $\begin{array}{l}\text { ISCOR } 1983 \\
12.50 \% 01 / 03 / 03 \\
\underline{\text { IS59 (penultimate }} \\
\text { coupon: } 27 / 08 / 02 \text { ) }\end{array}$ & 0.2 & $\begin{array}{l}3 \% \\
\text { (Rest: IS57 } \\
\text { ZARm 7.5) }\end{array}$ & $01 / 02 / 83$ & $\begin{array}{l}\text { EIB } 199812 \\
1 / 4 \% 20 / 05 / 0 \\
3 \text { (pen. } \\
\text { coupon: } \\
15 / 05 / 02 \text { ) }\end{array}$ & $\begin{array}{l}\text { RSA 1981 } \\
12.5 \% 01 / 09 / 03 \\
\text { R106 } \\
\text { (penultimate } \\
\text { coupon: } \\
\text { 25/02/03) }\end{array}$ & $\begin{array}{l}\text { Jul } 00 \text { to } \\
\text { Apr } 02\end{array}$ \\
\hline $\begin{array}{l}\text { Investec } \\
\text { Bank }\end{array}$ & $\begin{array}{l}\text { Specialty \& } \\
\text { Other } \\
\text { Financial } \\
\text { Activities } \\
\end{array}$ & $\begin{array}{l}\text { INVESTEC } \\
\text { BANK LTD. } 2000 \\
16 \% 31 / 03 / 12 \\
\text { IV01 }\end{array}$ & 2016 & $\begin{array}{l}67 \% \\
\text { (Rest: IV02 } \\
\text { ZARm 1000 } \\
\text { since 31/3/03) } \\
\end{array}$ & $17 / 06 / 00$ & $\begin{array}{l}\text { EIB } 1999 \\
13 \% \\
31 / 08 / 10\end{array}$ & $\begin{array}{l}\text { RSA } 198913 \% \\
31 / 08 / 09-11 \\
\text { R153 }\end{array}$ & $\begin{array}{l}\text { Jul } 00 \text { to } \\
\text { May } 03\end{array}$ \\
\hline Nedcor Bank & Banking & $\begin{array}{l}\text { NEDCOR BANK } \\
\text { LTD. } 2001 \\
11.3 \% \text { 20/09/06 } \\
\text { NED1 }^{\mathbf{7 9}}\end{array}$ & 2000 & $\begin{array}{l}33 \% \\
\text { (Rest: NED2 } \\
\text { ZARm } 4000 \\
\text { since } 01 / 07 / 02 \text { ) }\end{array}$ & $20 / 09 / 01$ & $\begin{array}{l}\text { EIB 2001 } \\
11 \% \\
28 / 12 / 06\end{array}$ & $\begin{array}{l}\text { RSA } 1996 \\
12.50 \% \\
21 / 12 / 06 \text { R184 }\end{array}$ & $\begin{array}{l}\text { Sep } 01 \text { to } \\
\text { May } 03\end{array}$ \\
\hline SASOL & $\begin{array}{l}\text { Chemicals \& } \\
\text { Fuels }\end{array}$ & $\begin{array}{l}\text { SASOL } \\
\text { FINANCING } 200 \\
014 \% 30 / 06 / 03 \\
\frac{\text { SFL1 }}{\text { (penultimate }} \\
\text { coupon: } 23 / 12 / 02 \text { ) }\end{array}$ & 900 & $100 \%$ & $24 / 06 / 00$ & $\begin{array}{l}\text { EIB } 199812 \\
1 / 4 \% 20 / 05 / 0 \\
3 \text { (pen. } \\
\text { coupon: } \\
15 / 05 / 02 \text { ) }\end{array}$ & $\begin{array}{l}\text { RSA 1981 } \\
12.5 \% 01 / 09 / 03 \\
\text { R106 } \\
\text { (penultimate } \\
\text { coupon: } \\
\text { 25/02/03) }\end{array}$ & $\begin{array}{l}\text { Jul } 00 \text { to } \\
\text { Feb } 02\end{array}$ \\
\hline $\begin{array}{l}\text { Standard } \\
\text { Bank }\end{array}$ & Banking & $\begin{array}{l}\text { STANDARD } \\
\text { BANK SA. } 2000 \\
15.50 \% 01 / 06 / 05 \\
\underline{\text { SBK1 }}^{\mathbf{8 0}}\end{array}$ & 1200 & $\begin{array}{l}21 \% \\
\text { (Rest: SBK2 } \\
\text { ZARm 1500, } \\
\text { SBK3 } \\
\text { ZARm 2000, } \\
\text { SBK4 ZARm } \\
1000)\end{array}$ & $31 / 05 / 00$ & $\begin{array}{l}\text { EIB } 1999 \\
13 \% \\
03 / 06 / 05\end{array}$ & $\begin{array}{l}\text { RSA } 198413 \% \\
\text { 15/07/05 R124 }\end{array}$ & $\begin{array}{l}\text { Jul } 00 \text { to } \\
\text { May } 03\end{array}$ \\
\hline
\end{tabular}

Sources: Datastream; Bond Exchange of South Africa; annual reports.

${ }^{77}$ End-May 2003, except for IS59 and SFL1: end-December 2000. Principal amount outstanding at that time was equal to amount issued for all bonds.

${ }^{78}$ End May 2003, except for IS59 and SFL1: end-December 2000.

${ }^{79} 20 / 09 / 06$ is the exercise data of the first call option, not the maturity date; maturity date is 20/09/2011.

${ }^{80} 01 / 06 / 05$ is the exercise date of the first call option, not the maturity date (as wrongly indicated in Datastream), which is 01/06/2010. See BESA website (list of corporate bond issues and "Static Data" files) and Standard Bank Group (2002, p. 137), for the details of this bond. 
Table 2. History of Credit Ratings by the Republic of South Africa and Firms Analyzed

(Until May 31, 2003)

\begin{tabular}{|c|c|c|c|c|c|c|}
\hline Issuer & Date & \multicolumn{2}{|c|}{ Standard \& Poor's } & Date & \multicolumn{2}{|c|}{ Moody's } \\
\hline & & $\begin{array}{l}\text { Local Currency } \\
\text { Credit } \\
\text { Rating (Issuer) }\end{array}$ & $\begin{array}{l}\text { Foreign } \\
\text { Currency Credit } \\
\text { Rating (Issuer) }\end{array}$ & & $\begin{array}{l}\text { Domestic Currency } \\
\text { Bond Rating } \\
\text { (Senior Unsecured) }\end{array}$ & $\begin{array}{l}\text { Foreign Currency } \\
\text { Bond Rating } \\
\text { (Senior Unsecured) }\end{array}$ \\
\hline & & $\begin{array}{l}\text { Long } \\
\text { Term/Outlook }\end{array}$ & $\begin{array}{l}\text { Long } \\
\text { Term/Outlook }\end{array}$ & & $\begin{array}{l}\text { Long } \\
\text { Term/Outlook }\end{array}$ & $\begin{array}{l}\text { Long } \\
\text { Term/Outlook }\end{array}$ \\
\hline $\begin{array}{l}\text { Republic of } \\
\text { South Africa }\end{array}$ & $\begin{array}{l}\text { May 7, 2003 } \\
\text { Nov. 12, } 2002 \\
\text { Feb. 25, } 2000 \\
\text { March 6, } 1998 \\
\text { Nov. 20, } 1995 \\
\text { Oct. 3, } 1994 \\
\end{array}$ & $\begin{array}{l}\text { A/stable } \\
\text { A-/positive } \\
\text { A-/stable } \\
\text { BBB+/stable } \\
\text { BBB+/positive }\end{array}$ & $\begin{array}{l}\text { BBB/stable } \\
\text { BBB-/positive } \\
\text { BBB-/stable } \\
\text { BB+/stable } \\
\text { BB+/positive } \\
\text { BB/positive }\end{array}$ & $\begin{array}{l}\text { Feb. 26, 2003 } \\
\text { Nov. 29, } 2001 \\
\text { Oct. 12, } 2001 \\
\text { Feb. 7, 2000 } \\
\text { Oct. 2, } 1998 \\
\text { Jul. 17, } 1998 \\
\text { Mar. 7, } 1997 \\
\text { Nov. 20, } 1995 \\
\text { Oct. 3, 1994 } \\
\end{array}$ & $\begin{array}{l}\text { A2/stable } \\
\text { A2/stable } \\
\text { Baa1/rev. for up } \\
\text { Baa1/positive } \\
\text { Baa1/stable } \\
\text { Baa1/rev. for down } \\
\text { Baa1/negative } \\
\text { Baa1 }\end{array}$ & $\begin{array}{l}\text { Baa2/positive } \\
\text { Baa2/stable } \\
\text { Baa3/rev. for up } \\
\text { Baa3/positive } \\
\text { Baa3/stable } \\
\text { Baa3/rev. for down } \\
\text { Baa3/negative } \\
-- \\
\text { Baa3 }\end{array}$ \\
\hline ABSA Bank & Nov. 16, 1998 & BBBpi 2/ & & $\begin{array}{l}\text { Feb. 27, } 2003 \\
\text { Dec. 6, 2001 } \\
\text { Oct. 17, 2001 } \\
\text { Feb. 8, 2000 } \\
\text { Oct. 2, 1998 } \\
\text { Jul. 17, } 1998 \\
\text { Jan. 22, 1996 } \\
\end{array}$ & & $\begin{array}{l}\text { Baa2/positive 1/ } \\
\text { Baa2/stable 1/ } \\
\text { Ba1/rev. for up 1/ } \\
\text { Ba1/positive 1/ } \\
\text { Ba1/stable } 1 / \\
\text { Ba1/rev. for down 1/ } \\
\text { Ba1 1/ }\end{array}$ \\
\hline African Bank & & & & & & \\
\hline Harmony Gold & & & & & & \\
\hline Imperial Group & & & & & & \\
\hline ISCOR & & & & & & \\
\hline Investec Bank & & & & $\begin{array}{l}\text { Feb. 27, 2003 } \\
\text { Dec. } 6,2001 \\
\text { Oct. 17, } 2001 \\
\text { Feb. } 8,2000 \\
\text { Oct. } 2,1998 \\
\text { Jul. } 17,1998 \\
\text { Dec. 11, 1996 }\end{array}$ & & $\begin{array}{l}\text { Baa2/positive 1/ } \\
\text { Baa2/stable 1/ } \\
\text { Ba1/rev. for up 1/ } \\
\text { Ba1/positive 1/ } \\
\mathrm{Ba} 1 / \text { stable } 1 / \\
\mathrm{Ba} 1 / \text { rev. for down } 1 / \\
\mathrm{Ba} 1 \text { 1/ }\end{array}$ \\
\hline Nedcor & Nov. 16, 1998 & BBBpi 2/ & & $\begin{array}{l}\text { Feb. 27, } 2003 \\
\text { Dec. 6, 2001 } \\
\text { Oct. 17, } 2001 \\
\text { Feb. } 8,2000 \\
\text { Oct. 2, 1998 } \\
\text { Jul. 17, } 1998 \\
\text { Jan. 22, } 1996\end{array}$ & & $\begin{array}{l}\text { Baa2/positive 1/ } \\
\text { Baa2/stable } 1 / \\
\text { Ba1/rev. for up 1/ } \\
\text { Ba1/positive 1/ } \\
\text { Ba1/stable } 1 / \\
\text { Ba1/rev. for down 1/ } \\
\text { Ba1 1/ }\end{array}$ \\
\hline Sasol & Feb. 19, 2003 & & $\mathrm{BBB} /$ stable & & & \\
\hline Standard Bank & Nov. 16, 1998 & BBBpi 2/ & & $\begin{array}{l}\text { Feb. 27, } 2003 \\
\text { Dec. 6, } 2001 \\
\text { Oct. 17, } 2001 \\
\text { Feb. 8, 2000 } \\
\text { Oct. 2, } 1998 \\
\text { Jul. 17, } 1998 \\
\text { Jan. 22, } 1996\end{array}$ & & $\begin{array}{l}\text { Baa2/positive 1/ } \\
\text { Baa2/stable 1/ } \\
\text { Ba1/rev. for up 1/ } \\
\text { Ba1/positive 1/ } \\
\mathrm{Ba} 1 / \text { stable } 1 / \\
\text { Ba1/rev. for down 1/ } \\
\text { Ba1 1/ }\end{array}$ \\
\hline
\end{tabular}

Sources: Websites of Moody's Investors Service and Standard \& Poor's

Notes:

1/ Long-Term Bank Deposit Ratings. These ratings are all equal to the Country Ceiling for Foreign Currency Bank Deposits.

2/ "pi" = Public information Rating. Ratings with a "pi" subscript are based on an analysis of an issuer's published financial information, as well as additional information in the public domain. They do not, however, reflect in-depth meetings with an issuer's management and are therefore based on less-comprehensive information than ratings without a "pi" subscript. 
Table 3. The Determinants of Corporate Default Premia: Expected Impact

\begin{tabular}{|c|c|c|c|}
\hline Type of Risk & & Determinant & $\begin{array}{c}\text { Expected Impact } \\
\text { on Corporate } \\
\text { Default Premium }\end{array}$ \\
\hline Systemic & \multicolumn{2}{|c|}{ Sovereign default risk $\left(s^{s o v}\right)$} & + \\
\hline \multirow{7}{*}{ Firm-specific } & \multicolumn{2}{|c|}{ Leverage (quasi-debt-to-firm-value) ratio $(d)$} & + \\
\hline & \multicolumn{2}{|c|}{ Firm-value volatility $\left(\sigma_{V}\right)$} & + \\
\hline & \multicolumn{2}{|c|}{ Interest rate volatility $\left(\sigma_{r}\right)$} & + or insignificant \\
\hline & \multicolumn{2}{|c|}{ Time to maturity $(\tau)$} & + \\
\hline & \multicolumn{2}{|l|}{ Liquidity $(l)$} & - \\
\hline & \multirow[b]{2}{*}{ Interaction terms } & Interest rate volatility*leverage $\left(\sigma_{r} \cdot d\right)$ & + \\
\hline & & Time to maturity*leverage $(\tau \cdot d)$ & - \\
\hline
\end{tabular}


Table 4. Data Sources and Measurement of Variables

\begin{tabular}{|c|c|c|c|c|}
\hline \multicolumn{2}{|c|}{ Determinant } & \multicolumn{2}{|c|}{ Sub-components } & \multirow[t]{2}{*}{ Source } \\
\hline Variable & Measurement & Symbol & Explanation & \\
\hline \multirow[t]{2}{*}{$\begin{array}{l}\text { Corporate spread } \\
\left(s_{t}\right)\end{array}$} & \multirow[t]{2}{*}{$S C O R=y-r f$} & $y$ & $\begin{array}{l}\text { Yield to maturity of } \\
\text { corporate bond }\end{array}$ & BESA \\
\hline & & $r f$ & $\begin{array}{l}\text { Yield to maturity of } \\
\text { corresponding risk-free } \\
\text { (supranational) bond }\end{array}$ & Datastream \\
\hline $\begin{array}{l}\text { Sovereign default } \\
\text { spread }\left(s_{t}^{\text {sov }}\right)\end{array}$ & $S S O V=s o v-r f$ & sov & $\begin{array}{l}\text { Yield to maturity of the } \\
\text { corresponding } \\
\text { government bond }\end{array}$ & BESA \\
\hline \multirow[t]{5}{*}{$\begin{array}{l}\text { Leverage (quasi- } \\
\text { debt-to-firm-value } \\
\text { ratio) }\left(d_{t}\right)\end{array}$} & \multirow{5}{*}{$\begin{array}{l}\text { (1) } D 1=B 1 \cdot P R F / V 1, \\
\text { where } V 1=E+P T \cdot B 1 \\
\text { (2) } D 2=B 2 \cdot P R F / V 2, \\
\text { where } V 2=E+P T \cdot B 2\end{array}$} & $B 1, B 2$ & $\begin{array}{l}\text { Face value of total firm } \\
\text { debt (B2 includes } \\
\text { customer deposits for the } \\
\text { financial institutions) }\end{array}$ & Bloomberg \\
\hline & & $P R F$ & Price of risk-free bond & Datastream \\
\hline & & $E$ & $\begin{array}{l}\text { Market value of firm } \\
\text { equity }\end{array}$ & Datastream \\
\hline & & $P T$ & $\begin{array}{l}\text { Market price of traded } \\
\text { debt }\end{array}$ & Datastream \\
\hline & & $V 1, V 2, V 3$ & Value of the firm & Calculated \\
\hline $\begin{array}{l}\text { Firm-value } \\
\text { volatility }\left(\sigma_{V}\right)\end{array}$ & $\begin{array}{l}\text { (1) } S V 1000 D \text {, where } \\
\sigma_{V} \text { in } \sigma_{E}=\sigma_{V} \frac{V 1 \Phi\left(h_{1}\right)}{E}, \\
\text { with } \\
h_{1}=\frac{-\ln (D 1)+\frac{1}{2} \sigma_{V}^{2} \tau}{\sigma_{V} \sqrt{\tau}} \cdot 81 \\
\text { (2) } S V 12 M \text { and } S V 24 M= \\
\text { stdev }\left[\ln \left(\frac{V 3_{t}}{V 3_{t-1}}\right)\right] \sqrt{12} \\
\text { over a } 12 \text { or } 24 \text { months } \\
\text { trailing sample, respectively. }\end{array}$ & $\begin{array}{l}\sigma_{E}=\operatorname{stdev}\left(u_{t}\right) \sqrt{261} \\
\text { where } u_{t} \text { is the daily } \\
\text { log-return on the } \\
\text { stock, and stdev is } \\
\text { the rolling standard } \\
\text { deviation over the } \\
\text { preceding } 1000 \\
\text { trading days. }\end{array}$ & $\begin{array}{l}\text { Annualized equity } \\
\text { volatility over the } \\
\text { preceding } 1000 \text { trading } \\
\text { days }\end{array}$ & Datastream \\
\hline
\end{tabular}

${ }^{81}$ See Appendix I-B for details about the numerical method to solve for $\sigma_{V}$. 
Table 4. Data Sources and Measurement of Variables (Concluded)

\begin{tabular}{|l|l|l|l|l|}
\hline $\begin{array}{l}\text { Interest rate } \\
\text { volatility }\left(\sigma_{r}\right)\end{array}$ & $\begin{array}{l}(1) \operatorname{SIGSPOTM} \\
\text { stdev }(\Delta r) \sqrt{12}\end{array}$ & $\begin{array}{l}\text { 3-month Bankers' } \\
(2) \operatorname{SIGRFM}= \\
\text { stdev }(\Delta r f) \sqrt{12}\end{array}$ & $\begin{array}{l}\text { Acceptance rate (proxy } \\
\text { for short-term interest } \\
\text { rate) }\end{array}$ & Datastream \\
\hline $\begin{array}{l}\text { Time to maturity } \\
(\tau)\end{array}$ & $M=\operatorname{LFFL}(-3)$ & LFFL & $\begin{array}{l}\text { Number of days from } \\
\text { settlement date until } \\
\text { maturity date (expressed } \\
\text { in years) }\end{array}$ & Datastream \\
\hline Liquidity $(l)$ & TOVC & $\begin{array}{l}\text { Amount traded (of a } \\
\text { given bond) during } \\
\text { month }\end{array}$ & BESA \\
\hline
\end{tabular}

Table 5. Descriptive Statistics of Variables

\begin{tabular}{|c|c|c|c|c|c|c|c|}
\hline Variable & $\begin{array}{l}\text { Corporate } \\
\text { Spread } \\
(S C O R)\end{array}$ & $\begin{array}{l}\text { Firm-Value } \\
\text { Volatility } \\
\text { (SV1000D ) }\end{array}$ & $\begin{array}{l}\text { Time to } \\
\text { Maturity } \\
(M)\end{array}$ & $\begin{array}{l}\text { Leverage } \\
\text { Ratio (D1) }\end{array}$ & $\begin{array}{c}\text { Liquidity } \\
\text { (Turnover } \\
\text { Value, } \\
\text { TOVC) }\end{array}$ & $\begin{array}{l}\text { Interest Rate } \\
\text { Volatility } \\
\text { (SIGSPOTM ) }\end{array}$ & $\begin{array}{l}\text { Sovereign } \\
\text { Spread } \\
\text { (SSOV) }\end{array}$ \\
\hline & (Basis points) & (Percent) & (Years) & - & (ZAR million) & (Percent) & (Basis points) \\
\hline Mean & 154.02 & 23.35 & 4.15 & 0.51 & 203.00 & 1.01 & 22.43 \\
\hline Median & 140.53 & 21.12 & 3.42 & 0.55 & 72.15 & 1.02 & 23.70 \\
\hline Maximum & 413.26 & 53.02 & 11.67 & 0.91 & 4080.00 & 1.73 & 112.05 \\
\hline Minimum & -26.47 & 0.59 & 0.75 & 0.08 & 0.00 & 0.25 & -105.09 \\
\hline Std. Dev. & 75.26 & 14.50 & 2.74 & 0.23 & 486.00 & 0.34 & 32.91 \\
\hline Observations & 237 & 237 & 237 & 237 & 237 & 237 & 237 \\
\hline Cross-sections & 9 & 9 & 9 & 9 & 9 & 9 & 9 \\
\hline
\end{tabular}

Source: Authors' calculations. 


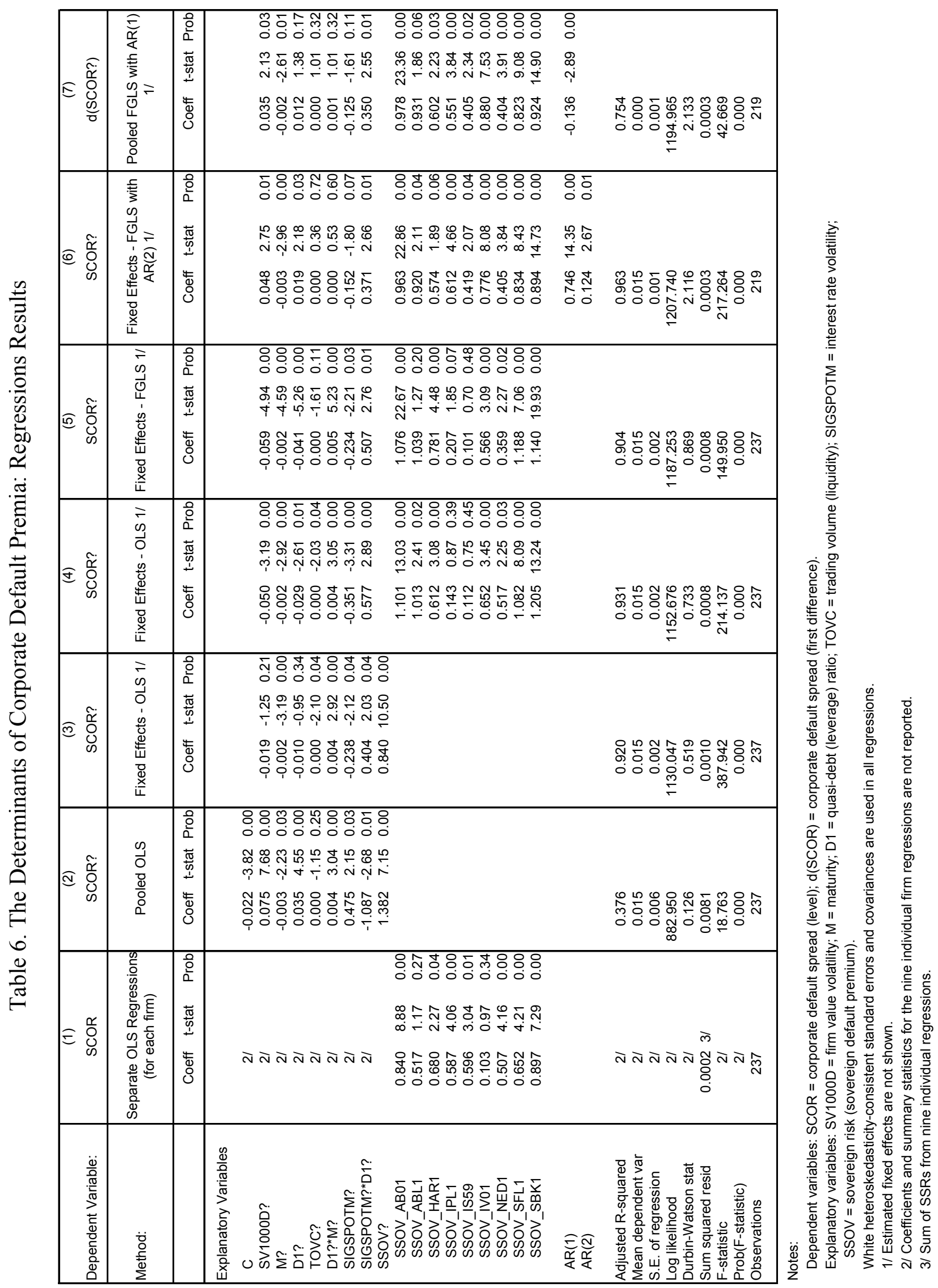


Table 7: The Determinants of Corporate Default Premia: Summary of Empirical Results

\begin{tabular}{|c|c|c|c|c|}
\hline \multirow[t]{2}{*}{ Type of Risk } & \multirow{2}{*}{\multicolumn{2}{|c|}{ Determinant }} & \multicolumn{2}{|c|}{$\begin{array}{c}\text { Impact on Corporate Default } \\
\text { Spreads }\end{array}$} \\
\hline & & & Expected & Estimated \\
\hline Systematic & \multicolumn{2}{|c|}{ Sovereign default risk $(\mathrm{SSOV}) * * *$} & + & + \\
\hline \multirow{7}{*}{ Firm-specific } & \multicolumn{2}{|c|}{ Leverage ratio $(D 1)^{* *}$} & + & + \\
\hline & \multicolumn{2}{|c|}{ Firm-value volatility $(S V 1000 D) * * *$} & + & + \\
\hline & \multicolumn{2}{|c|}{ Interest rate volatility $(S I G S P O T M) *$} & + (or insignif.) & - (insignif.) \\
\hline & \multicolumn{2}{|c|}{ Time to maturity $(M)^{* * *}$} & + & - \\
\hline & \multicolumn{2}{|c|}{ Liquidity $(T O V C)$} & - & insignif. \\
\hline & \multirow{2}{*}{$\begin{array}{l}\text { Interaction } \\
\text { Terms }\end{array}$} & $\operatorname{SIGSPOTM} \cdot D 1 * * *$ & + & + \\
\hline & & $D 1 \cdot M$ & - & insignif. \\
\hline
\end{tabular}

Note: ${ }^{* *}, * *, *$ mean the variable is statistically significant at the 1,5 , and 10 percent level, respectively.

Table 8. Variance Decompositions of Corporate Default Premia in Levels and First Differences

(In Percent)

\begin{tabular}{lccccc}
\hline & $\begin{array}{c}\text { Firm-Specific } \\
\text { Factors }\end{array}$ & Sovereign Risk & Fixed Effects & Residuals & Total \\
\hline Level & -1 & 13 & 93 & -5 & 100 \\
First Differences & 5 & 61 & - & 34 & 100 \\
\hline
\end{tabular}

Source: Authors' calculations. 
Figure 1. Firm Bond Yields and Corresponding Sovereign and Risk-Free Yields (In percent, daily data, beginning of available data until June 4, 2003)

Panel 1: ABSA Bank AB01

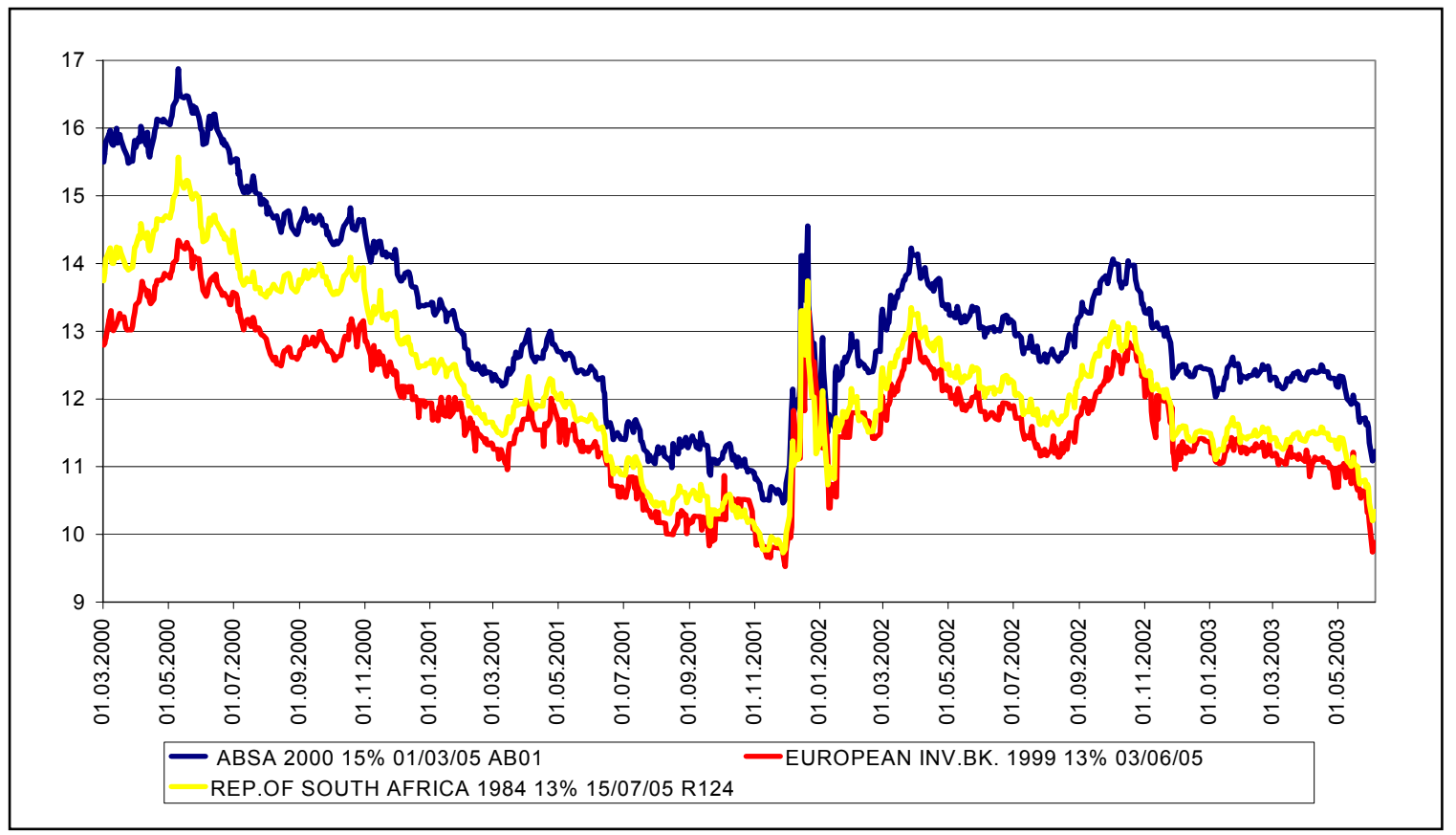

Panel 2: African Bank ABL1

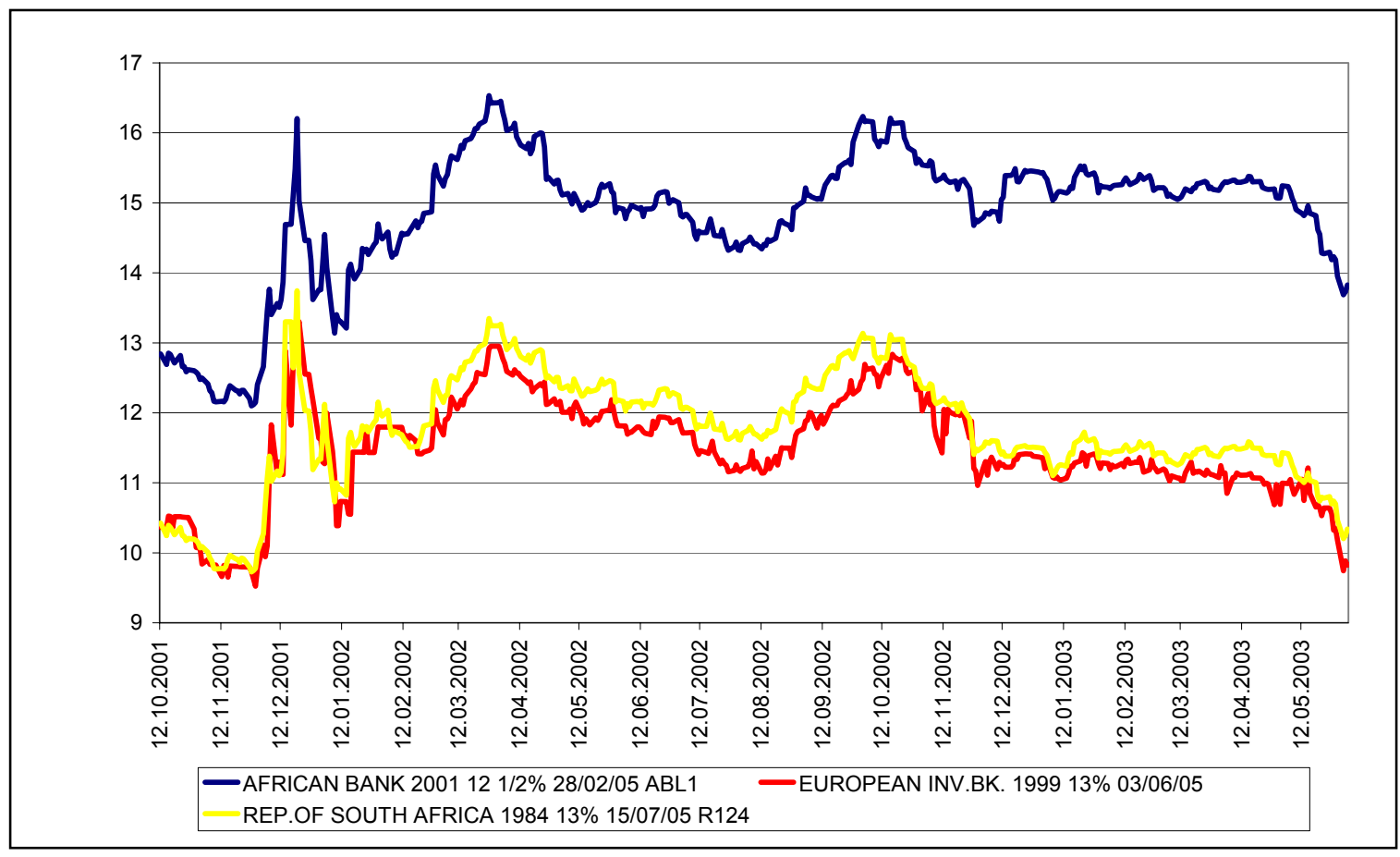


Panel 3: Harmony Gold HAR1

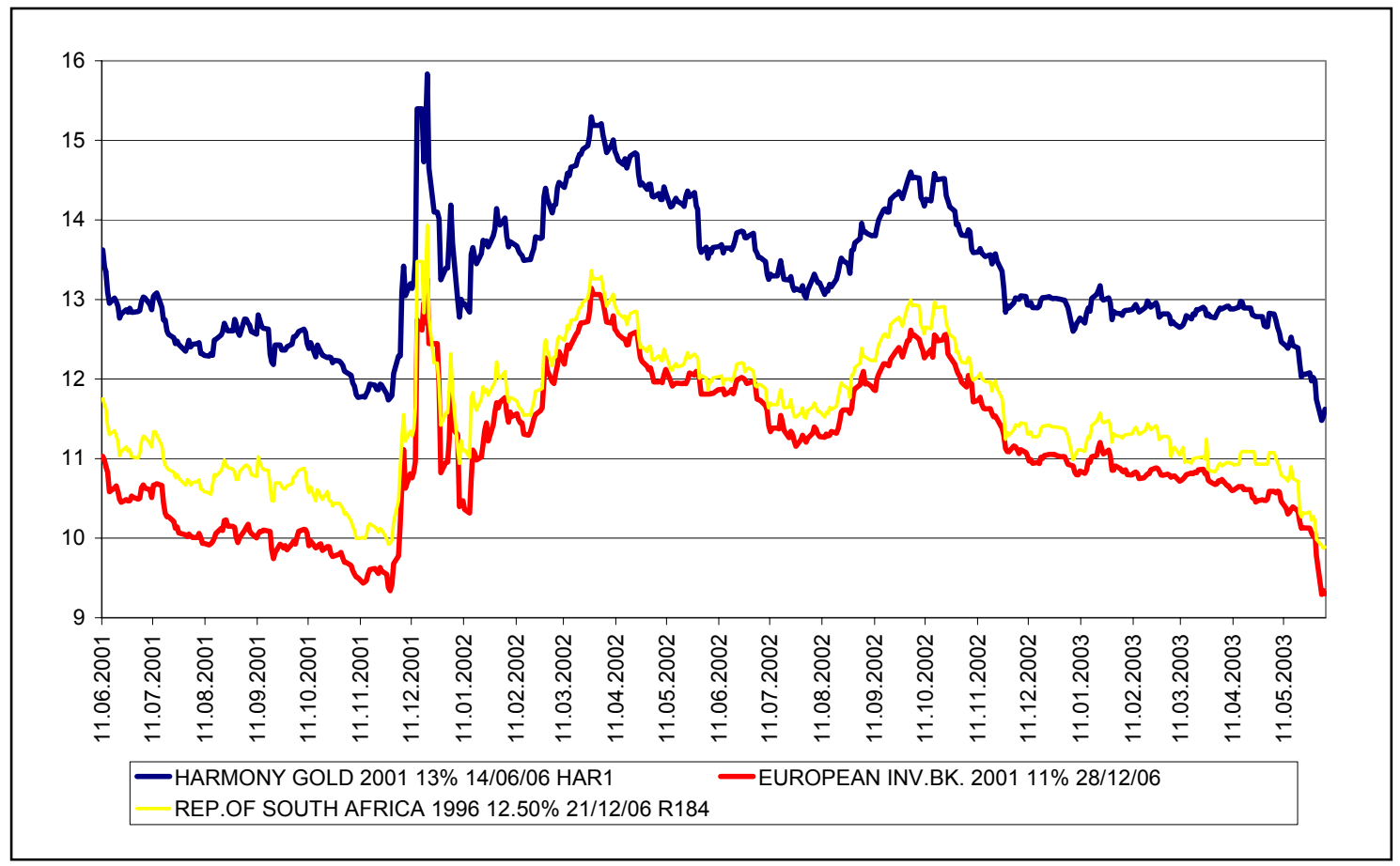

Panel 4: Imperial Group IPL1

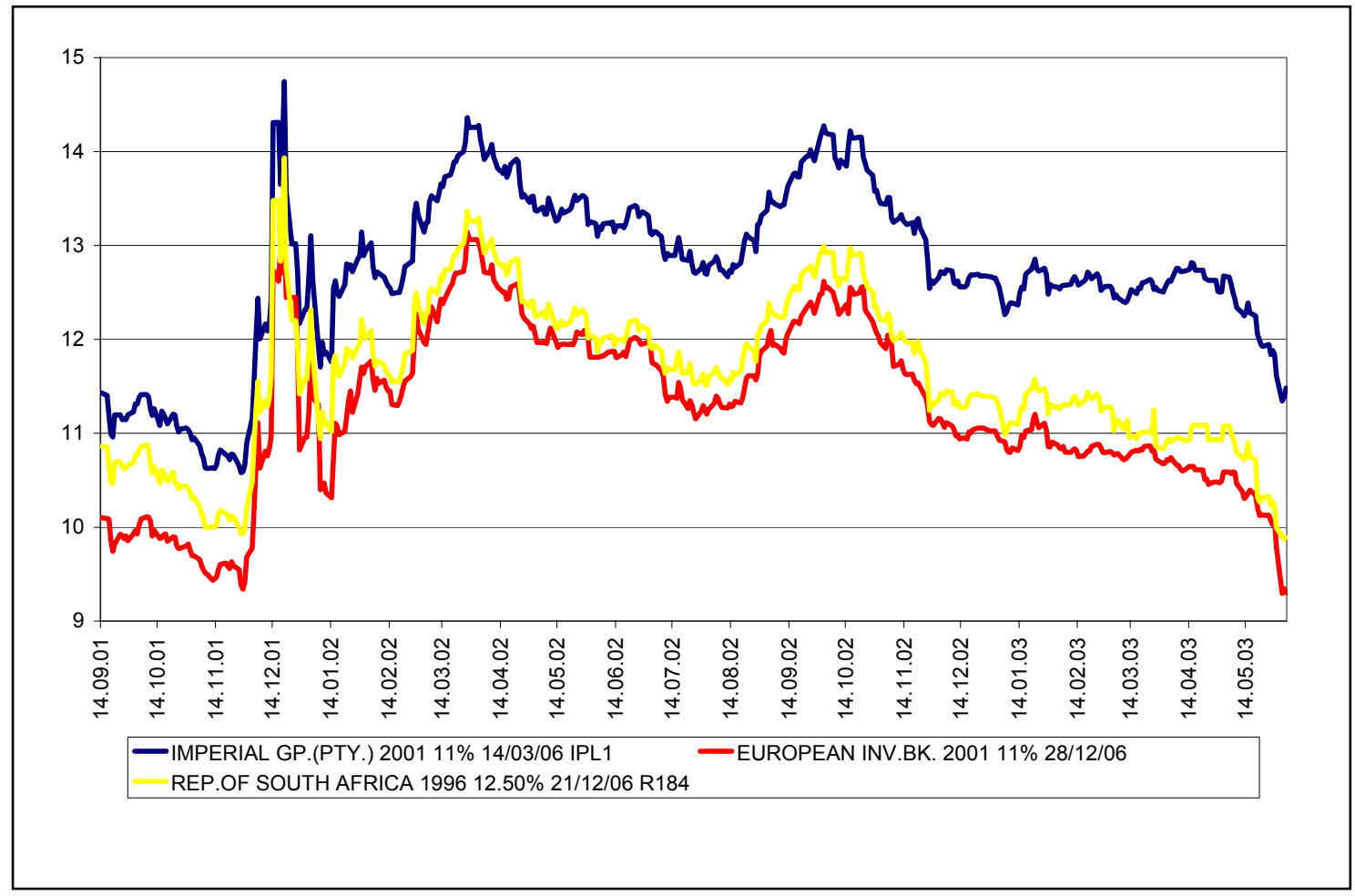


Panel 5: ISCOR IS59

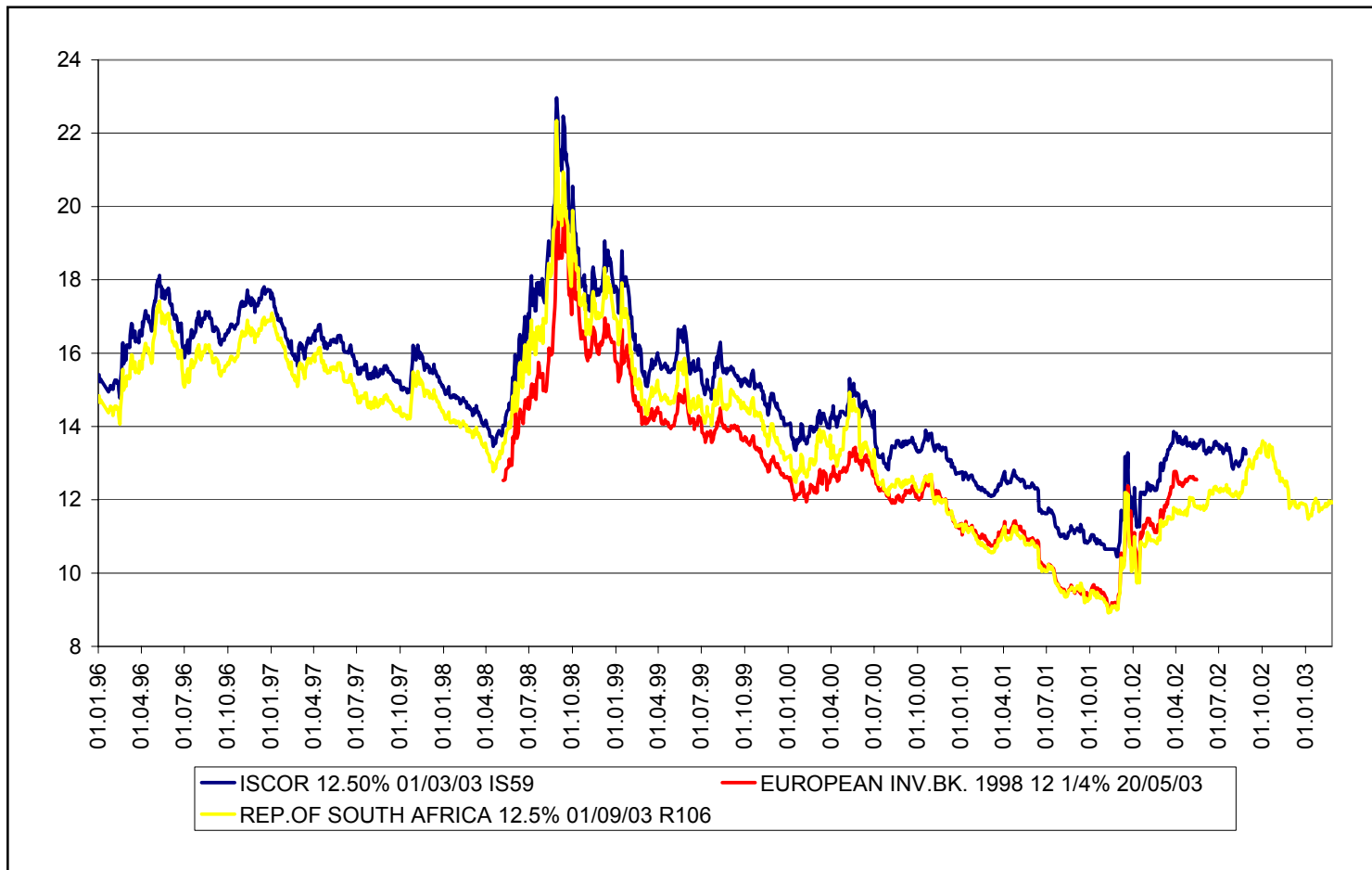

Panel 6: Investec Bank IV01

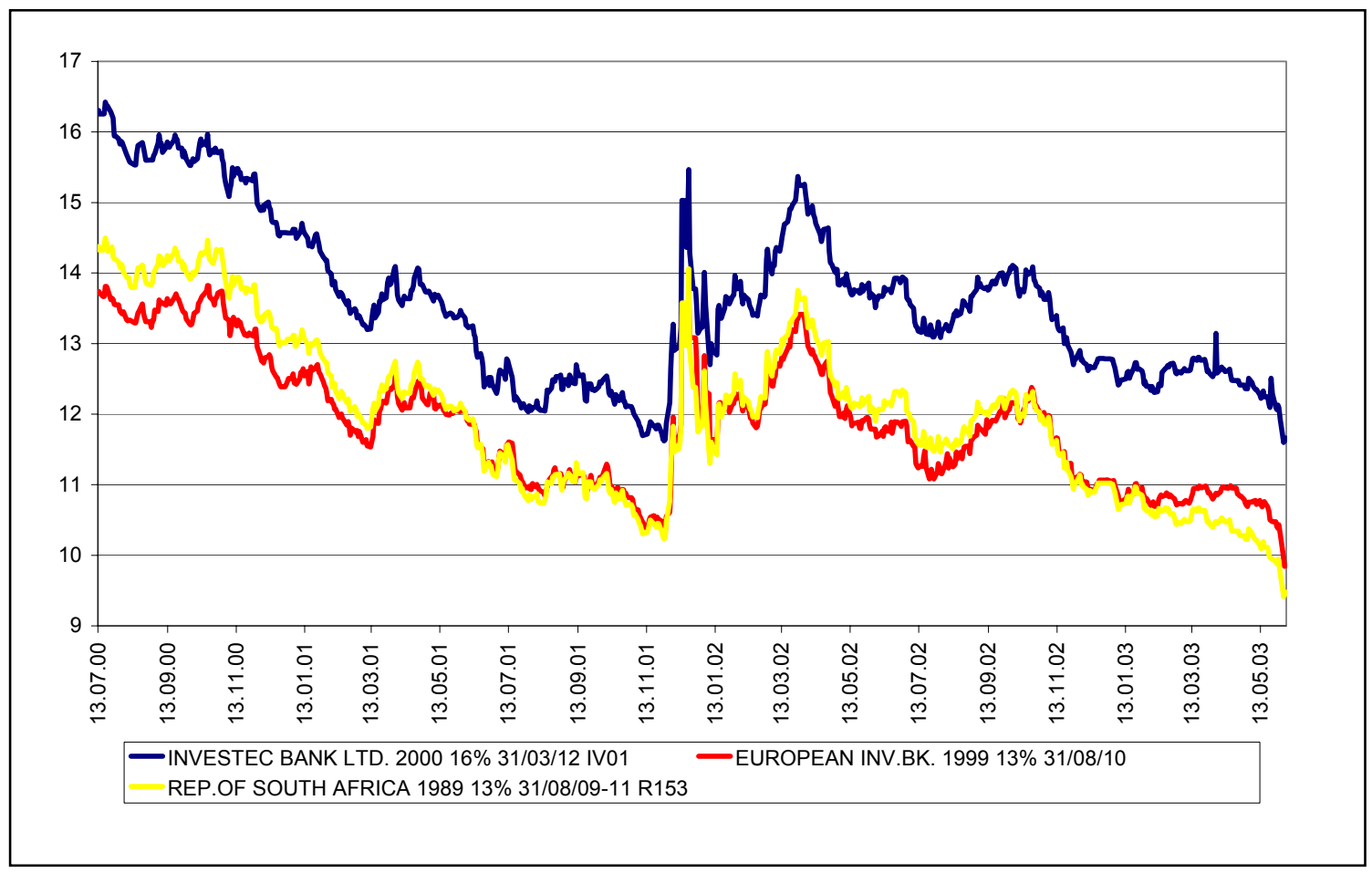


Panel 7: Nedcor NED1

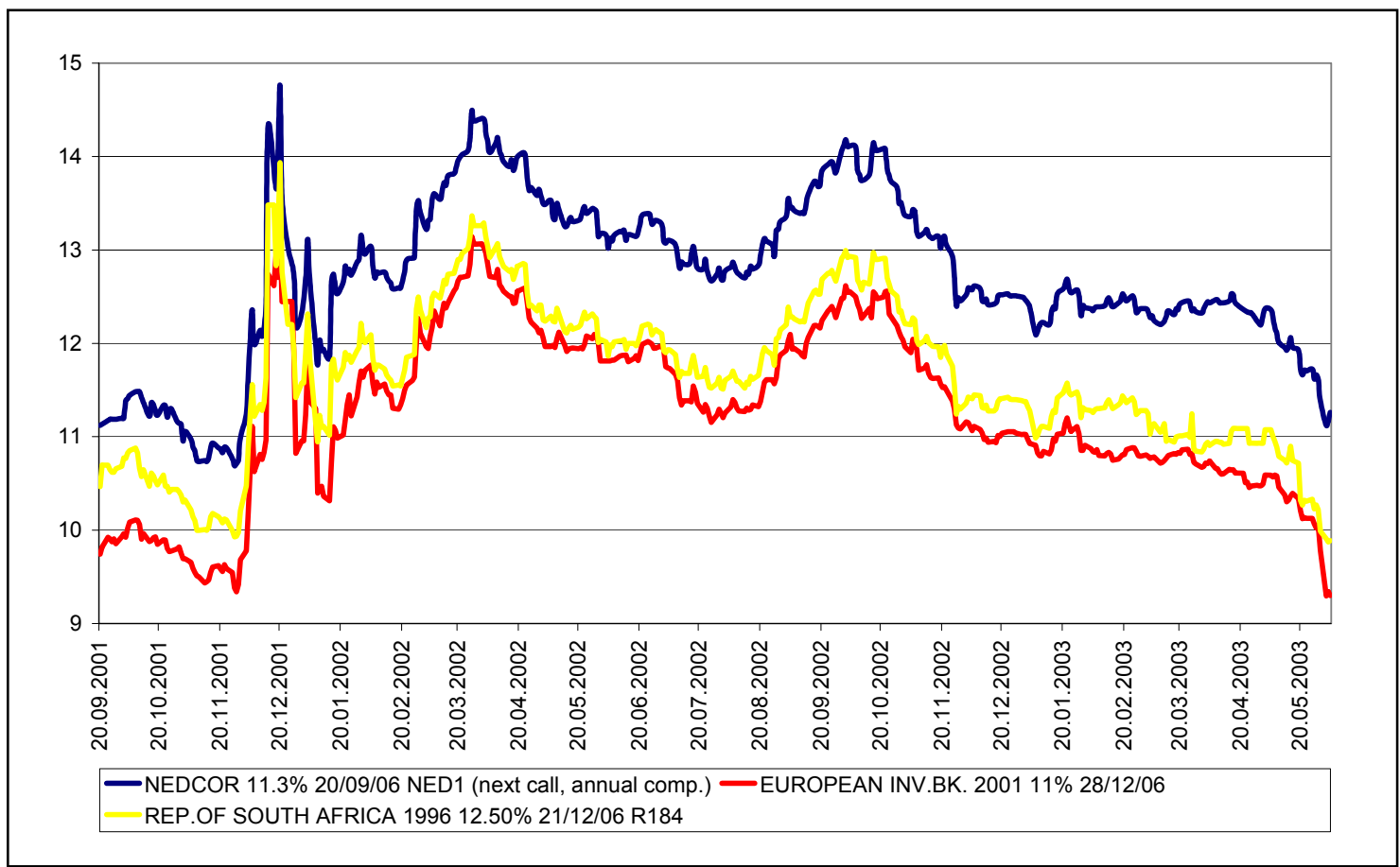

Panel 8: Sasol SFL1

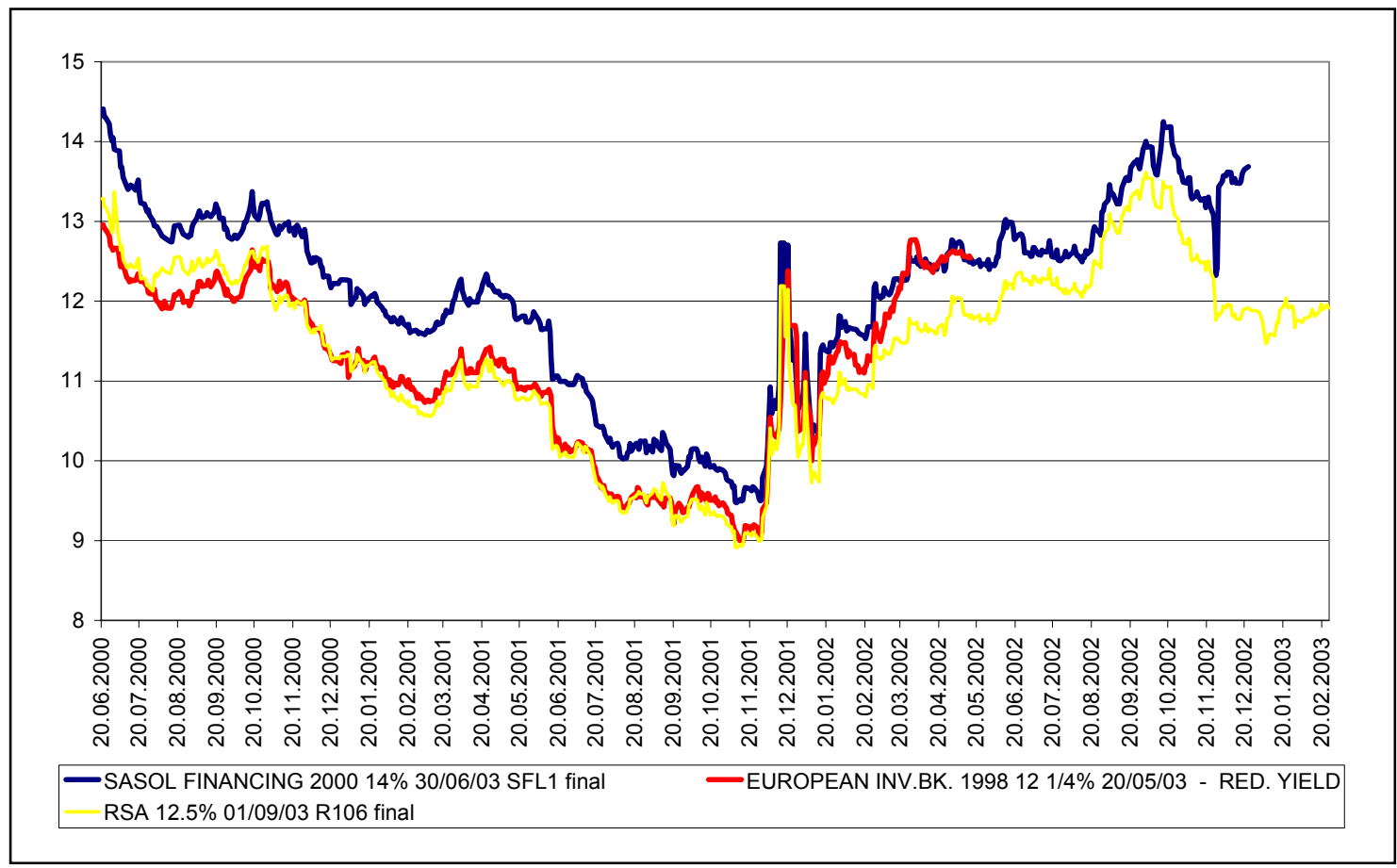


Panel 9: Standard Bank SBK1

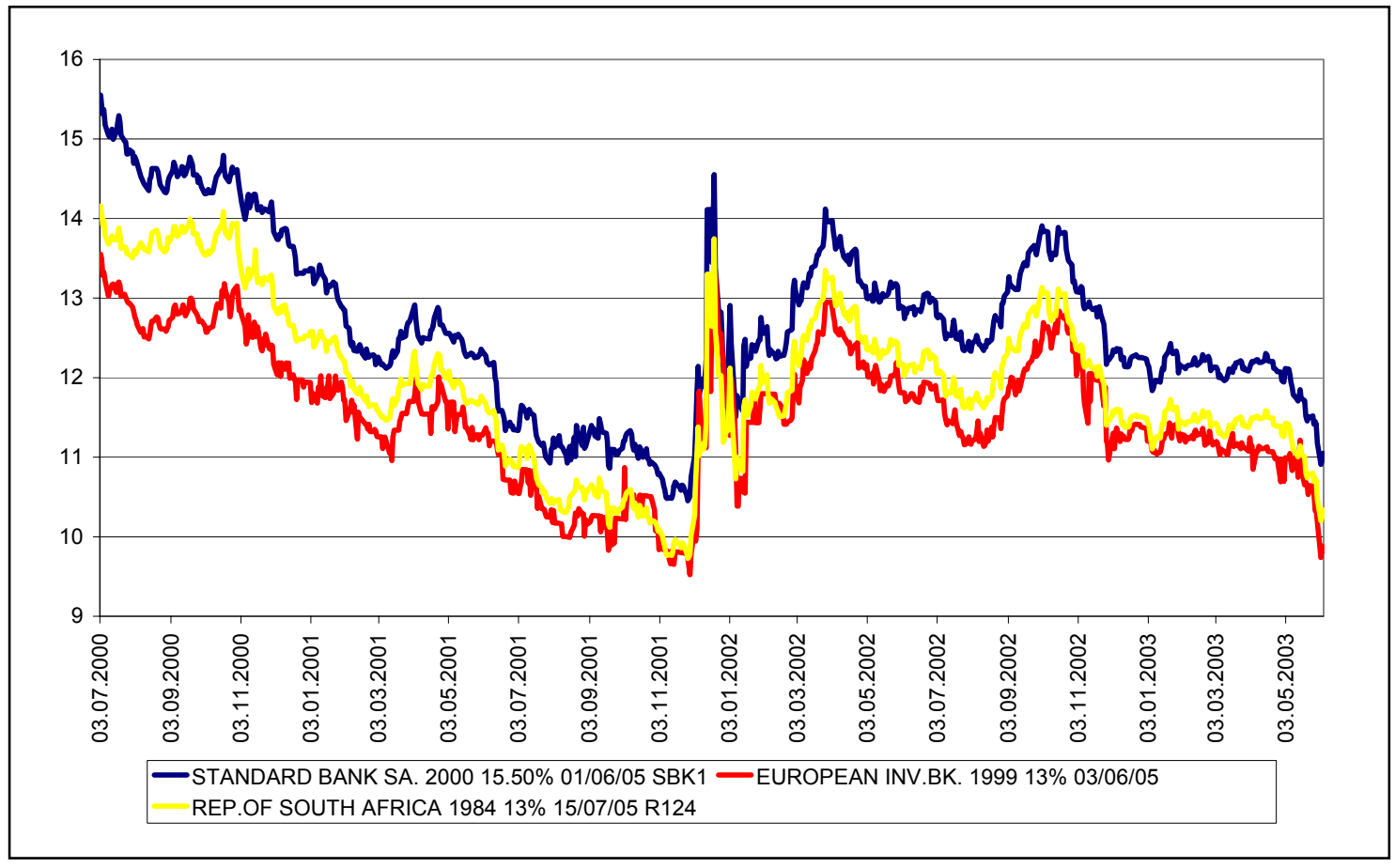

Sources: Datastream; Bond Exchange of South Africa. 
Figure 2. South African Corporate Default Premia, July 2000-May 2003 (In percent, monthly data)

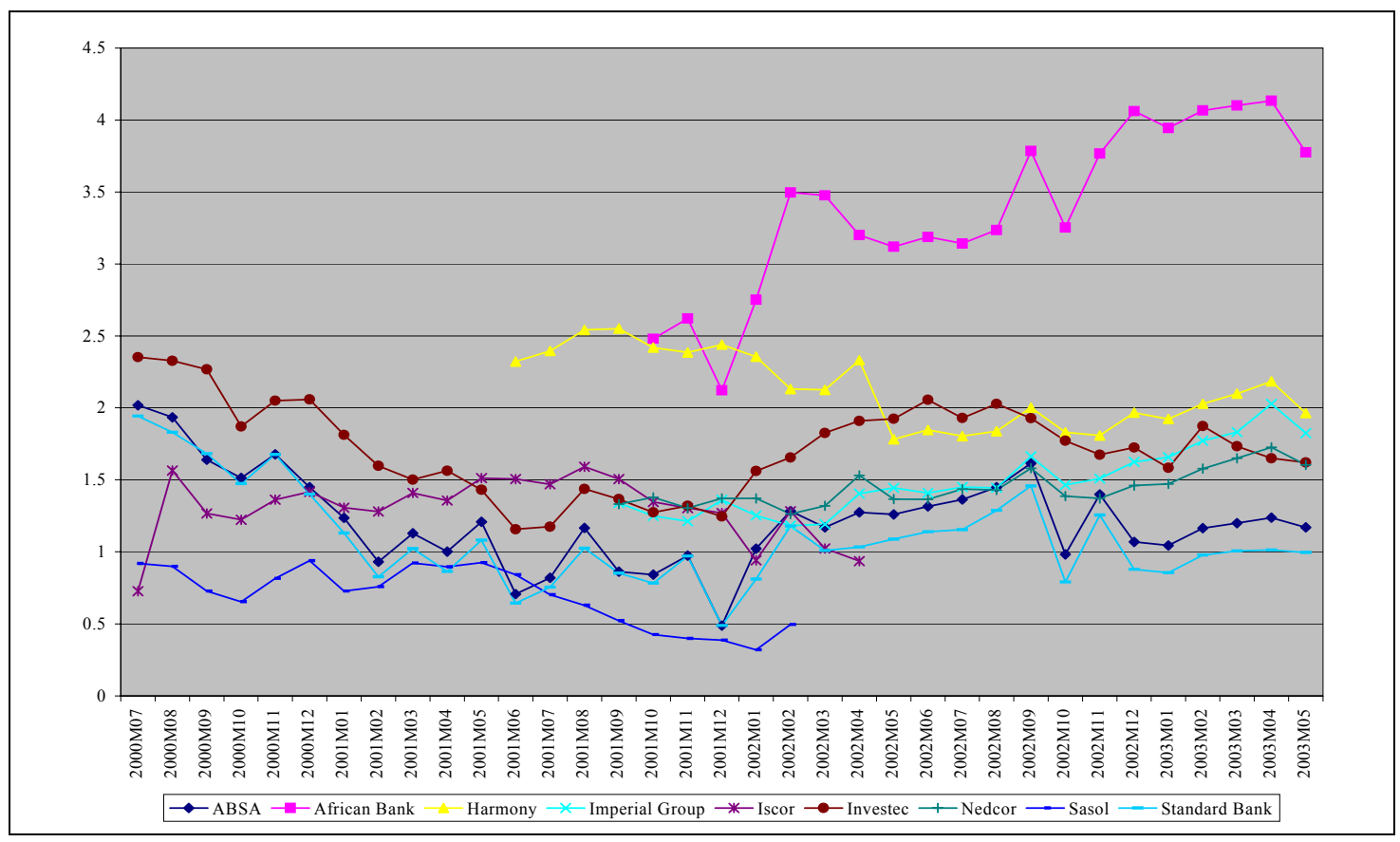

Figure 3. South African Sovereign Default Premia, Corresponding to the Corporate Default Premia, July 2000-May 2003

(In percent, monthly data)

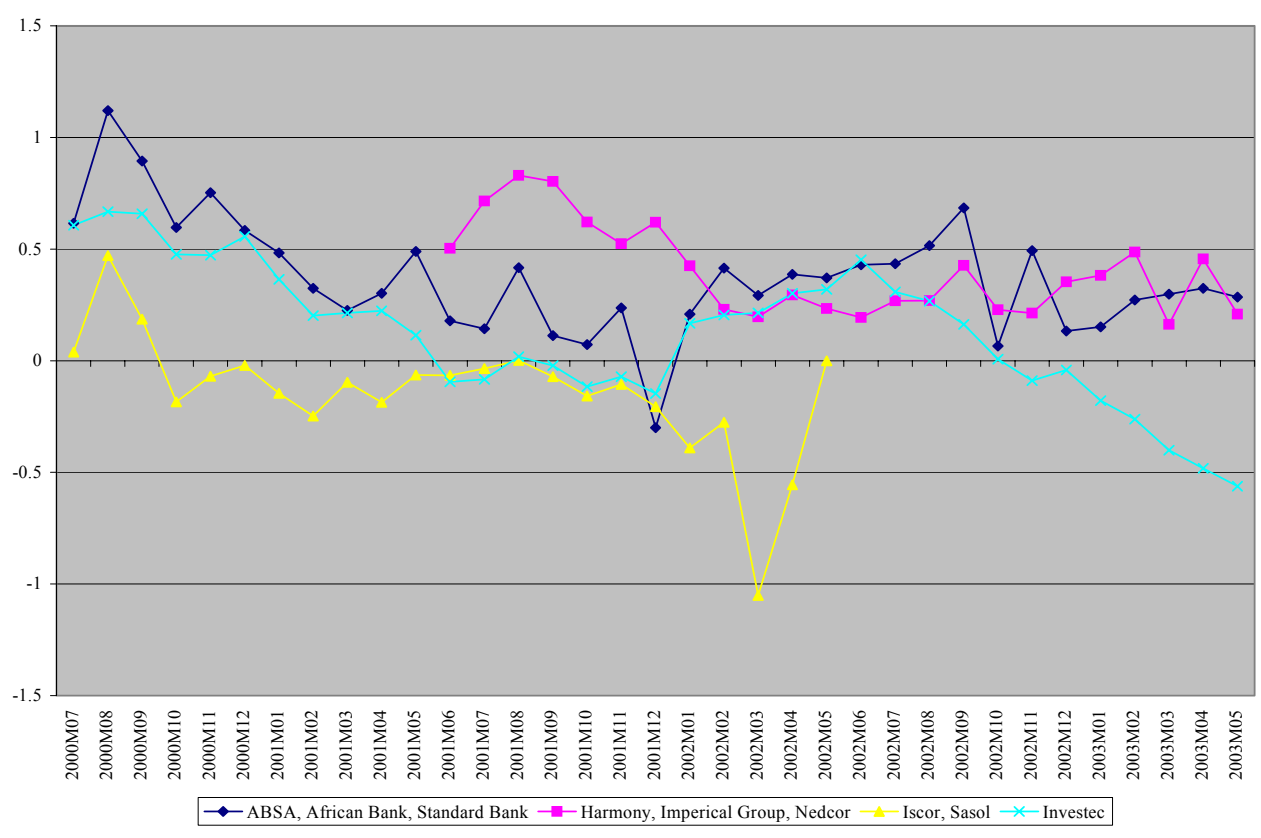

Source: Authors' calculations based on data from Datastream and Bond Exchange of South Africa. 


\section{REFERENCES}

Athanassakos, George, and Peter Carayannopoulos, 2001, "An Empirical Analysis of the Relationships of Bond Yields and Macro-Economic Factors," Applied Financial Economics, Vol. 11 (2), pp. 197-207.

Baltagi, Badi H., 1995, Econometric Analysis of Panel Data (Chichester: John Wiley and Sons).

Basel Committee on Banking Supervision, 2004, "International Convergence of Capital Measurement and Capital Standards. A Revised Framework," June (Basel: Bank for International Settlements).

Bielecki, Tomasz R., and Marek Rutkowski, 2002, Credit Risk: Modeling, Valuation and Hedging (Berlin: Springer).

Black, Fischer, and Myron Scholes, 1973, "The Pricing of Options and Corporate Liabilities," Journal of Political Economy, Vol. 81 (3), pp. 637-59.

Boehmer, Ekkehart, and William L. Megginson, 1990, "Determinants of Secondary Market Prices for Developing Country Syndicated Loans," Journal of Finance, Vol. 45 (5), pp. 1517-40.

Bond Exchange of South Africa, 1997, Bond Pricing Formula-Specifications (Melrose: Bond Exchange of South Africa).

—, 2003 , Mark to Market (MTM). (Melrose: BESA). Available at: http://www.bondex.co.za/indices/mtm/index.html.

Briys, Eric, and François De Varenne, 1997, "Valuing Risky Fixed Rate Debt: An Extension," Journal of Financial and Quantitative Analysis, Vol. 32 (2), pp. 239-49.

Caouette, John B., Edward I Altman, and Paul Narayanan, 1998, Managing Credit Risk. The Next Great Financial Challenge (New York: John Wiley and Sons).

Collin-Dufresne, Pierre, Robert S. Goldstein, and J. Spencer Martin, 2001, "Determinants of Credit Spread Changes,” Journal of Finance, Vol. 56 (6), pp. 2177-208.

Collin-Dufresne, Pierre, and Bruno Solnik, 2001, "On the Term Structure of Default Premia in the Swap and LIBOR Markets," Journal of Finance, Vol. 56 (3), pp. 1095-115.

Cook, Timothy Q., and Patric H. Hendershott, 1978, “The Impact of Taxes, Risk and Relative Security Supplies on Interest Rate Differentials," Journal of Finance, Vol. 33 (4), pp. 1173-86. 
Cossin, Didier, and Hugues Pirotte, 2001, Advanced Credit Risk Analysis (Chichester: John Wiley and Sons).

Das, Sanjiv, and Peter Tufano, 1996, "Pricing Credit Sensitive Debt When Interest Rates, Credit Ratings and Credit Spreads are Stochastic," Journal of Financial Engineering, Vol. 5 (2), pp. 161-98.

Duffie, Darrell, and David Lando, 2001, “Term Structures of Credit Spreads with Incomplete Accounting Information," Econometrica, Vol. 69 (3), pp. 633-64.

Duffie, Darrell, and Kenneth J. Singleton, 1999, "Modeling Term Structures of Defaultable Bonds," Review of Financial Studies, Vol. 12 (4), pp. 687-720.

Durbin, Erik, and David T. Ng, 2001, "The Sovereign Ceiling and Emerging Market Corporate Bond Spreads," (unpublished paper; St. Louis and Ithaca: Olin School of Business and Cornell University).

_ 2005, "The Sovereign Ceiling and Emerging Market Corporate Bond Spreads," Journal of International Money and Finance (forthcoming).

Edwards, Sebastian, 1984, "LDC Foreign Borrowing and Default Risk: An Empirical Investigation, 1976-80," American Economic Review, Vol. 74 (4), pp. 726-34.

— 1986, "The Pricing of Bonds and Bank Loans in International Markets: An Empirical Analysis of Developing Countries' Foreign Borrowing," European Economic Review, Vol. 30, pp. 565-89.

Eichengreen, Barry, and Ricardo Hausmann, 1999, "Exchange Rates and Financial Fragility,”NBER Working Paper No. 7418 (Cambridge, Massachusetts): National Bureau of Economic Research).

Eichengreen, Barr, and Ashoka Mody, 1998, "What Explains Changing Spreads on Emerging-Market Debt? Fundamentals or Market Sentiment?" NBER Working Paper No. 6408 (Cambridge, Massachusetts: National Bureau of Economic Research).

Elton, Edwin J., Martin, J. Gruber, Deepak Agrawal, and Christopher Mann, 2001, "Explaining the Rate Spread on Corporate Bonds," Journal of Finance, Vol. 54 (1), pp. 247-77.

Fisher, Lawrence, 1959, "Determinants of Risk Premiums on Corporate Bonds," Journal of Political Economy, Vol. 57 (3), pp. 217-37.

Fitch Ratings, 2001, Rating Above the Sovereign: An Update (London: Fitch Ratings Ltd.). 
Fons, Jerome S., 1994, "Using Default Rates To Model the Term Structure of Credit Risk," Financial Analysts Journal, Vol. 50, pp. 25-32.

Grandes, Martin, Marcel Peter, and Nicolas Pinaud, 2003, "The Currency Premium and Local-Currency Denominated Debt Costs in South Africa," OECD Development Centre Working Paper No. 230 (Paris: OECD Development Centre).

Greene, William H., 1993, Econometric Analysis (Upper Saddle River, New Jersey: Prentice Hall, second ed.).

Ho, Thomas, and Ronald F. Singer, 1984, "The Value of Corporate Debt with a Sinking Fund Provision," Journal of Business, Vol. 57 (3), pp. 315-36.

Hsiao, Cheng, 1986, Analysis of Panel Data (Cambridge: Cambridge University Press).

Hsu, Jason C., Jesús Saá-Requejo, and Pedro Santa Clara, 2002, "Bond Pricing with Default Risk," Anderson Graduate School of Management Working Paper (Los Angeles: University of California).

Jarrow, Robert, David Lando, and Stuart Turnbull, 1997, "A Markov Model of the Term Structure of Credit Spreads," Review of Financial Studies, Vol. 10 (2), pp. 481-523.

Jarrow, Robert and Stuart Turnbull, 1995, "Pricing Derivatives on Financial Securities Subject to Credit Risk," Journal of Finance, Vol. 50 (1), pp. 53-85.

Kamin, Steven B., and Karsten Von Kleist, 1999, “The Evolution and Determination of Emerging Market Credit Spread in the 1990s," BIS Working Paper No. 68 (Basel: Bank for International Settlements).

Lando, David, 1998, “On Cox Processes and Credit Risky Bonds," Review of Derivatives Research, Vol. 2 (2/3), pp. 99-120.

Larrain, Guillermo, Helmut Reisen, and Julia von Maltzan, 1997, "Emerging Market Risk and Sovereign Credit Ratings," OECD Development Centre Technical Papers No. 124 (Paris: OECD Development Centre).

Litterman, Robert, and Thomas Iben, 1991, "Corporate Bond Valuation and the Term Structure of Credit Spreads," Journal of Portfolio Management, Vol. 17, pp. 52-64.

Longstaff, Francis A., and Eduardo S. Schwartz, 1995, “A Simple Approach to Valuing Risky Fixed and Floating Rate Debt," Journal of Finance, Vol. 50 (3), pp. 789-819.

Madan, Dilip B., and Haluk Unal, 1998, "Pricing the Risks of Default," Review of Derivative Research, Vol. 2, pp. 121-60.

Merton, Robert C., 1974, "On the Pricing of Corporate Debt: The Risk Structure of Interest Rates," Journal of Finance, Vol. 29 (2), pp. 449-70. 
Moody's Investors Service, 2001a, June 7, Press Release: "Change in Country Ceiling Approach, Foreign Currency Bond Ratings of 38 Issuers Reviewed” (New York Moody's Investors Service). Available at: http://www.moodys.com.

— , 2001b, "Revised Country Ceiling Policy," Rating Methodology, June (New York: Moody's Investors Service).

Nelson, Charles R., and Andrew F. Siegel, 1987, "Parsimonious Modeling of Yield Curves," Journal of Business, Vol. 60 (4), pp. 473-89.

Obstfeld, Maurice, and Kenneth Rogoff, 1996, Foundations of International Macroeconomics (Cambridge, Massachusetts, and London: MIT Press).

Peter, Marcel, 2002, "Estimating Default Probabilities of Emerging Market Sovereigns: A New Look at a Not-So-New Literature," HEI Working Paper No. 6 (Geneva: Graduate Institute of International Studies).

Pye, Gordon, 1974, "Gauging the Default Premium," Financial Analysts Journal, Vol. 30 (1), pp. 49-52.

Rand Merchant Bank, 2001, The Development of the South African Corporate Bond Market (Johannesburg: Rand Merchant Bank).

Saá-Requejo, Jesús, and Pedro Santa Clara, 1997, "Bond Pricing with Default Risk," Anderson Graduate School of Management Working Paper No. 13 (Los Angeles: University of California).

Sarig, Oded, and Arthur Warga, 1989, "Some Empirical Estimates of the Risk Structure of Interest Rates," Journal of Finance, Vol. 44 (5), pp. 1351-60.

Shimko, David, Naohiko Tejima, and Donald Van Deventer, 1993, "The Pricing of Risky Debt When Interest Rates Are Stochastic," Journal of Fixed Income (September), pp. 58-65.

Standard \& Poor's, 2001, "Sovereign Risk and Ratings Above the Sovereign," Commentary, July 23 (New York: Standard and Poor's).

Standard Bank Group, 2002, Annual Report (Johannesburg: Standard Bank Group).

Vasicek, O., 1977, “An Equilibrium Characterization of the Term Structure,” Journal of Financial Economics, Vol. 5, pp. 177-88.

Westphalen, Michael, 2001, "The Determinants of Sovereign Bond Credit Spread Changes," (unpublished Working Paper; Lausanne: École des HEC and FAME). 